\title{
Native Cu from the oceanic crust: Isotopic insights into native metal origin
}

\author{
Vesselin M. Dekov $^{\mathrm{a}, *}$, Olivier Rouxel ${ }^{\mathrm{a}, \mathrm{b}}$, Dan Asael ${ }^{\mathrm{a}}$, Ulf Hålenius ${ }^{c}$, Frans Munnik $^{\mathrm{d}}$ \\ a IFREMER, Centre de Brest, Department of Marine Geosciences, 29280 Plouzané, France \\ b Marine Chemistry and Geochemistry Department, Woods Hole Oceanographic Institution, Woods Hole, MA \\ 02543, USA \\ ${ }^{\mathrm{C}}$ Department of Mineralogy, Swedish Museum of Natural History, Box 50007, SE-104 05 Stockholm, Sweden \\ d Institute of Ion Beam Physics and Materials Research, Helmholtz-Zentrum Dresden-Rossendorf, D-01328 \\ Dresden, Germany \\ *: Corresponding author : Vesselin M. Dekov, tel.: + 33298224953 ; fax: + 33298224570 ; \\ email address : Vesselin.Dekov@ifremer.fr
}

\begin{abstract}
:
Ocean drilling has revealed that, although a minor mineral phase, native $\mathrm{Cu}$ ubiquitously occurs in the oceanic crust. $\mathrm{Cu}$ isotope systematics for native $\mathrm{Cu}$ from a set of occurrences from volcanic basement and sediment cover of the oceanic crust drilled at several sites in the Pacific, Atlantic and Indian oceans constrains the sources of $\mathrm{Cu}$ and processes that produced $\mathrm{Cu}^{0}$. We propose that both hydrothermallyreleased $\mathrm{Cu}$ and seawater were the sources of $\mathrm{Cu}$ at these sites. Phase stability diagrams suggest that $\mathrm{Cu}^{0}$ precipitation is favored only under strictly anoxic, but not sulfidic conditions at circum-neutral pH even at low temperature. In the basaltic basement, dissolution of primary igneous and potentially hydrothermal Cusulfides leads to $\mathrm{Cu}^{0}$ precipitation along veins. The restricted $\mathrm{Cu}$-isotope variations $\left(\delta^{65} \mathrm{Cu}=0.02-0.19 \%\right.$ ) similar to host volcanic rocks suggest that $\mathrm{Cu}^{0}$ precipitation occurred under conditions where $\mathrm{Cu}^{+}-\mathrm{species}$ were dominant, precluding $\mathrm{Cu}$ redox fractionation. In contrast, the $\mathrm{Cu}$-isotope variations observed in the $\mathrm{Cu}^{0}$ from sedimentary layers yield larger $\mathrm{Cu}$-isotope fractionation $\left(\delta^{65} \mathrm{Cu}=0.41-0.95 \%\right.$ ) suggesting that $\mathrm{Cu}^{0}$ precipitation involved redox processes during the diagenesis, with potentially seawater as the primary $\mathrm{Cu}$ source. We interpret that native $\mathrm{Cu}$ precipitation in the basaltic basement is a result of low temperature $\left(20^{\circ}-65^{\circ} \mathrm{C}\right)$ hydrothermal processes under anoxic, but not $\mathrm{H}_{2} \mathrm{~S}$-rich conditions. Consistent with positive $\delta^{65} \mathrm{Cu}$ signatures, the sediment cover receives major $\mathrm{Cu}$ contribution from hydrogenous (i.e., seawater) sources, although hydrothermal contribution from plume fallout cannot be entirely discarded. In this case, disseminated hydrogenous and/or hydrothermal $\mathrm{Cu}$ might be diagenetically remobilized and reprecipitated as $\mathrm{Cu}^{0}$ in reducing microenvironment.
\end{abstract}

\section{Highlights}

native $\mathrm{Cu}$ is a minor mineral phase in the oceanic crust $\mathrm{Cu}^{0}$ precipitation is favored under anoxic, but not sulfidic conditions at $\mathrm{pH} \sim 7 \rightarrow \mathrm{Cu}^{+}$-species are dominant in the basaltic basement $\rightarrow \mathrm{Cu}^{2+}$-species dominate in the solutions in the sedimentary layer $\rightarrow \mathrm{Cu}^{0}$ precipitation in the basaltic basement is related to seawater-rock interaction sediment cover receives major $\mathrm{Cu}$ contribution from hydrogenous (seawater) source.

Keywords : Cu-isotopes ; Deep-Sea Drilling Project ; native Cu ; Ocean Drilling Project ; oceanic crust alteration

\section{Introduction}

Copper is amongst the elements which most commonly occur in zero-valence state in nature. As such, native $\mathrm{Cu}\left(\mathrm{Cu}^{0}\right)$ deposits have long been one of the most important $\mathrm{Cu}$ resources 
(e.g., Wang et al., 2006; Cooper et al., 2008; Pinto et al., 2011). In general, the large $\mathrm{Cu}^{0}$ deposits are genetically related to either magmatic or hydrothermal Cu-sulfide deposits (Cornwall, 1956; Amstutz, 1977; Brown, 2006) and are often considered to form as products of their supergene alteration. Although our knowledge on $\mathrm{Cu}^{0}$ mode of formation is based almost exclusively on occurrences from the continents where it occurs in a wide range of rocks, $\mathrm{Cu}^{0}$ has been reported to occur in fragments of ancient oceanic crust (ophiolites) (Nagle et al., 1973; Abrajano and Pasteris, 1989; Bai et al., 2000; Miller et al., 2003; Ikehata et al., 2011), in the igneous basement of the recent oceanic crust (von der Borch et al., 1974; Kennett et al., 1975; Ovenshine et al., 1975; Talwani et al., 1976; Roberts et al., 1984; Leinen et al., 1986; LeHuray, 1989; Puchelt et al., 1996), in marine sediments (Berger and von Rad, 1972; Hollister et al., 1972; Zemmels et al., 1972; Schlanger et al., 1976; Siesser, 1978; Knox, 1985; Jenkyns, 1976; Marchig et al., 1986; Dekov et al., 1999) and in seafloor massive sulfides (Minniti and Bonavia, 1984; Hannington et al., 1988). Almost all these works but two (Hannington et al., 1988; Dekov et al., 1999) are either brief reports of $\mathrm{Cu}^{0}$ occurrences without any particular study of the mineral, or mere speculations on the native $\mathrm{Cu}$ origin. There is no systematic study on $\mathrm{Cu}^{0}$ from the oceanic crust and, therefore, we know little about the $\mathrm{Cu}^{0}$ formation in this setting.

Recent development in mass spectrometry techniques has led to a tremendous growth of research on transitional metal isotopes such as $\mathrm{Fe}, \mathrm{Cu}, \mathrm{Zn}$ and $\mathrm{Mo}$ (Johnson et al., 2004; Anbar and Rouxel, 2007). In their pioneering work on the natural variations of the $\mathrm{Cu}$-isotopes ${ }^{65} \mathrm{Cu}$ and ${ }^{63} \mathrm{Cu}$, Walker et al. (1958) and Shields et al. (1965) reported $\mathrm{Cu}$-isotope variations of several per mil in $\mathrm{Cu}$-ores. These results were confirmed by later more precise isotope measurements using multicollector inductively-coupled plasma mass-spectrometry (MC-ICP-MS) (Maréchal et al., 1999; Zhu et al., 2000; Larson et al., 2003; Graham et al., 2004; Rouxel et al., 2004; Mason et al., 2005; Maher and Larson, 2007; Mathur et al., 2009; Palacios et al., 2011). This new capability 
for $\mathrm{Cu}$-isotope measurement demonstrates the great potential of $\mathrm{Cu}$-isotopes as new tracers for the study of modern and ancient hydrothermal systems and $\mathrm{Cu}$ deposits [skarn (Maher and Larson, 2007), porphyry (Mathur et al., 2009) and supergene (Mathur et al., 2005)]. In particular, it is hoped that $\mathrm{Cu}$-isotopes may provide a powerful tool for getting insights into the source of $\mathrm{Cu}$ and the mechanisms of $\mathrm{Cu}^{0}$ mineralization in the oceanic crust.

In this study we have investigated a set of native $\mathrm{Cu}$ occurrences from a range of basement rocks and sediments drilled at several Deep-Sea Drilling Project (DSDP) and Ocean Drilling Project (ODP) sites aiming at: (1) characterization of $\mathrm{Cu}^{0}$ from the oceanic crust; (2) determining the sources of $\mathrm{Cu}$ and the processes that produced $\mathrm{Cu}^{0}$ with an ultimate goal to set a ground for further interpretations of the origin of native $\mathrm{Cu}$ deposits on land.

\section{Geologic setting}

We present brief lithologic-stratigraphic descriptions of the DSDP/ODP cores (from top to bottom) where we have found $\mathrm{Cu}^{0}$ particles, with more particular attention to the core units with native $\mathrm{Cu}$ findings. Details on lithology and stratigraphy of the investigated cores can be found elsewhere (Hollister et al., 1972; von der Borch et al., 1974; Bolli et al., 1978; Leinen et al., 1986; Eldholm et al., 1987).

\subsection{Site 105}

The cored section at Site 105 (DSDP Leg 11) starts with silty hemipelagic clay (Q) overlying hemipelagic clay (Tertiary), multicolored clay $\left[\mathrm{K}_{2}{ }^{\mathrm{cm}}(?)-\mathrm{Pg}_{2}(?)\right]$, black clay $\left(\mathrm{K}_{1}{ }^{\text {bar }}-\right.$ $\left.\mathrm{K}_{2}{ }^{\mathrm{cm}}\right)$, white and gray limestone $\left(\mathrm{J}_{3}{ }^{\text {tit }}-\right.$ Neocomian$)$, red clayey limestone $\left(\mathrm{J}_{3}{ }^{\text {ox-kim }}\right)$ and basalt $\left(\mathrm{J}_{3}\right)$ 
(Fig. 1; Hollister et al., 1972). A vein of tiny $\mathrm{Cu}^{0}$ crystals occurs in the pale red, reddish-brown and greenish intercalations of clayey limestone $\sim 10 \mathrm{~m}$ above the basalt unit (Fig. 1). This limestone is composed of calcite, clays, hematite and quartz and shows a variety of slump structures. The $\mathrm{Cu}^{0}$ vein is bordered by palagonite and it also shows palagonite filling the interstices between $\mathrm{Cu}^{0}$ crystals. The clayey limestone covers pyroclastics that are altered to montmorillonite. Below the pyroclastics recrystallized limestones (with high-Mg calcite) occur at the contact with the underlying basalt that is highly fractured (veins of calcite) and altered.

\subsection{Site 216}

Drilling at Site 216 (DSDP Leg 22) cored sediments composed of nannofossil ooze and chalk with foraminifera $\left(\mathrm{Pg}_{3}{ }^{3}-\mathrm{Q}_{1}\right)$, nannofossil chalk $\left(\mathrm{Pg}_{1}-\mathrm{Pg}_{3}{ }^{3}\right)$, glauconite-bearing micarb chalk and ash-bearing volcanic clay $\left(\mathrm{K}_{2}{ }^{\mathrm{ms}}\right)$, and basalt (Fig. 1; von der Borch et al., 1974). The recovered basement section is divided into four units (from top to bottom): (1) sedimentbasement interface consisting of a chlorite-rich limestone mixed with volcanic debris; (2) thin flows ( $<1 \mathrm{~m}$ thick) of medium dark gray vesicular and amygdaloidal basalts intercalated by chlorite-rich micritic limestone; (3) pale red oxidized scoriaceous basalt composed of aphanitic basaltic rocks passing gradually to a highly vesicular zone; (4) medium gray basalt containing few altered light olive gray zones enriched in opaques. The bottom of the drilled hole consists of alternating flows of highly vesicular basalt, amygdalar basalts, and patchy non-vesicular basalts.

The sediments overlying the igneous rocks at Site 216 were inferred to be deposited in a shallow-water environment. The basalts at this Site differ in composition, texture, and mineral paragenesis from typical mid-ocean ridge basalts (Bougault, 1974; Hekinian, 1974; Thompson et al., 1974). Most of the clinopyroxene and plagioclase in them are fresh, and only a small amount 
of them is altered into chlorite (Hekinian, 1974). However, there are light olive gray zones with a colorless pale-brown diopside-hedenbergite in a matrix of Fe-oxyhydroxides (Hekinian, 1974). These highly altered basalts may be related to a shallow hydrothermal discharge zone with precipitation of $\mathrm{Cu}$-sulfide in veins. Native copper occurs as vein filling in this localized hydrothermally altered zone.

\subsection{Site 364}

A thick sediment-rock sequence was drilled at Site 364 (DSDP Leg 40) with calcareous mud and clay $\left(\mathrm{N}_{2}{ }^{3}-\mathrm{Q}_{1}\right)$, marly nannofossil ooze and mud $\left(\mathrm{N}_{1}{ }^{2}-\mathrm{N}_{2}{ }^{1}\right)$, yellow-brown pelagic clay and radiolarian mud $\left(\mathrm{Pg}_{3}{ }^{2}-\mathrm{N}_{1}{ }^{2}\right)$, yellow-brown and brown nanno chalk and marly chalk $\left(\mathrm{K}_{2}{ }^{\text {st }}-\right.$ $\left.\mathrm{Pg}_{2}{ }^{2}\right)$, chalks, marly chalks and mudstones with sapropels $\left[\mathrm{K}_{2}{ }^{\mathrm{cm}}(?)-\mathrm{K}_{2}{ }^{\text {st }}\right]$, bluish-gray to olivegray limestone and marly limestone $\left[\mathrm{K}_{1}^{\mathrm{alb}}(?)\right]$, marly dolomitic limestone with sapropel $\left[\mathrm{K}_{1}{ }^{\mathrm{apt}}\right.$ $\mathrm{K}_{1}{ }^{\mathrm{alb}}($ ?) ] (Fig. 1; Bolli et al., 1978). It is supposed (Bolli et al., 1978) that the drilled sequence at this site covers evaporates. Within the drilled section two of the lithologic units contain carbonates or marly carbonates interbedded with black, finely laminated sapropels with up to $15 \% \mathrm{C}_{\text {org. }}$ and abundant pyrite. The native $\mathrm{Cu}$ occurrences are in the upper part of an oxidized sediment unit: dark yellowish-brown to olive marly nannofossil ooze at the top becoming yellowish-brown to gray pelagic clay toward the bottom. The overlaying sediment units are composed of dark olive-gray to black calcareous mud, which contain up to $4 \%$ pyrite indicating reducing conditions.

\subsection{Site 597}


The drilled sequence at Site 597C (DSDP Leg 92) comprises zeolitic clay, clay bearing to clayey nannofossil ooze, ash layer, olivine-bearing aphyric basalt, olivine-free basalt, and olivinebearing basalt (Fig. 1; Leinen et al., 1986). Native Cu particles and veins occur in the basalts. The basalt has undergone incipient to moderate alteration. According to Peterson et al. (1986) there are 3 secondary mineral assemblages in the altered basalts at this Site which formed in the following order: (1) trioctahedral chlorite and talc; (2) goethite and smectite; (3) calcite and celadonite. The sequential precipitation of these mineral assemblages denotes high water/rock ratios and time-varying conditions of temperature (early $>200^{\circ} \mathrm{C}$ to late $<30^{\circ} \mathrm{C}$ ) and state of oxidation (early nonoxidative to late oxidative). The intensity of alteration decreases with depth, probably partly as a result of a decrease in vesicularity and fracture spacing (Leinen et al., 1986). Oxidative low-temperature seawater alteration is supposed to influence the upper portion (down to $120 \mathrm{~m}$ below seafloor) of the basaltic basement at Site 597C (Erzinger, 1986), whereas the lowermost basement was affected by a non-oxidative hydrothermal alteration occurring at higher temperature (Nishitani, 1986).

\subsection{Site 642}

Drilling at Site 642E (ODP Leg 104) recovered a long core of mud $\left(\mathrm{N}_{2}-\mathrm{Q}\right)$, nannofossil and radiolarian ooze $\left(\mathrm{N}_{1}{ }^{3}-\mathrm{N}_{2}\right)$, mud and nannofossil ooze $\left(\mathrm{N}_{1}{ }^{3}\right)$, nannofossil and radiolarian ooze $\left(\mathrm{N}_{1}{ }^{2}-\mathrm{N}_{1}{ }^{3}\right)$, mud and radiolarian ooze $\left(\mathrm{N}_{1}{ }^{1}-\mathrm{N}_{1}{ }^{2}\right)$, mud with volcanic ash $\left(\mathrm{Pg}_{2}\right)$, basalts, and andesites and basalts (Fig. 1; Eldholm et al., 1987). Native Cu occurs as disseminated blebs in groundmass and in veins in fine-grained, aphyric to phyric and vesicular gray basalt with subvertical fractures filled with smectite and calcite. It is supposed (Eldholm et al., 1987) that these igneous rocks were deposited under subaerial conditions. Throughout the igneous sequence 
there is a low-temperature suite of secondary minerals. Superimposed on this, there is a later, higher temperature overprint. Smectite, celadonite and calcite fill vesicles and fractures. This paragenesis may indicate a shift from nonoxygenated to oxygenated fluids. Early, lowtemperature alteration of the lower series has been overprinted by later, higher temperature (100$\left.130^{\circ} \mathrm{C}\right)$ effects.

\section{Material and methods}

We applied in the Integrated Ocean Drilling Program (IODP) for sediment and rock samples from all the $12 \mathrm{DSDP} / \mathrm{ODP}$ cores we were aware of that had been reported to contain native $\mathrm{Cu}$ occurrences (Fig. 1). Consequently, we were provided with 24 sediment and rock samples from 8 of those DSDP/ODP cores (Table 1). Preliminary descriptions of the native $\mathrm{Cu}$ occurrences not provided for this study from those four DSDP/ODP Sites (Fig. 1) can be found elsewhere (Kennett et al., 1975; Roberts et al., 1984; Knox, 1985; Puchelt et al., 1996).

All the sediment and rock samples were thoroughly investigated for metallic $\mathrm{Cu}$ particles using conventional stereo-microscope (Olympus SZ-ST). Although previously reported, we could not find any $\mathrm{Cu}^{0}$ particles in the samples from 3 of the DSDP/ODP cores (Fig. 1; Berger and von Rad, 1972; Jenkyns, H.C., 1976; Talwani et al., 1976) and therefore our study is based on samples from 5 cores. In total, we found and analyzed 26 single $\mathrm{Cu}^{0}$ particles from 9 discrete samples after crushing them with stainless steel hammer (Table 1). Six rock samples of those with native $\mathrm{Cu}$ particles were prepared as polished sections and investigated under optical microscope (Olympus BX60). Secondary electron images (SEI) and energy dispersive X-ray spectra (EDS) of native $\mathrm{Cu}$ occurrences were obtained on $\mathrm{C}$-coated specimens using a Hitachi 
S4300 scanning electron microscope (SEM) fitted with a solid state $\mathrm{Si}(\mathrm{Li})$ detector $(\mathrm{V}=8-20 \mathrm{kV}$, $\mathrm{I}=5-8 \mu \mathrm{A}$ ) using the INCA software package (Oxford Instruments).

Reflectance measurements on polished sections (two $\mathrm{Cu}^{0}$ specimens) in the visible spectrum (400-700 nm) were performed with a Zeiss MPM800 microscope photometer system, equipped with 10x/0.20 and 32x/0.40 Glycerine Ultrafluar objectives, adjusted to give a field of measurement with diameter of $30 \mu \mathrm{m}$. Measurements were carried out in air and in oil (Zeiss 518C, $\mathrm{n}=1.518$ ). The step size (equal to bandwidth) was $5 \mathrm{~nm}$, and the data were corrected for parasitic-light effects and standardized against SiC (Zeiss no. 846). Vickers microhardness $\left(\mathrm{H}_{\mathrm{v}}\right)$ was measured on three $\mathrm{Cu}^{0}$ particles in polished sections with a Shimadzu micro hardness tester type-M (load $25 \mathrm{~g}$, loading time $15 \mathrm{~s})$. One big ( 10x10 mm) native Cu flake [22-216-37-4 (114117)] was analyzed by X-ray diffraction (XRD) using a Philips PW1710 diffractometer (graphitemonochromatised $\mathrm{Cu} K_{\alpha}$ radiation, $\mathrm{PW} 1830$ generator, $40 \mathrm{kV}, 40 \mathrm{~mA}, 42-95^{\circ} 2 \theta$ scan, $0.02{ }^{\circ} 2 \theta$ step, $1 \mathrm{~s} / \mathrm{step})$. Peak positions were determined with the X'Pert Graphics and Identify program.

Concentrations of elements with $Z \geq 9$ (F) were acquired on carbon-coated polished sections of three $\mathrm{Cu}^{0}$ specimens using a Cameca SX50 electron microprobe (EMP) $(\mathrm{V}=20 \mathrm{kV}, \mathrm{I}=12 \mathrm{nA}$, electron beam diameter of $2 \mu \mathrm{m}$ and native $\mathrm{Cu}$ standard). The compositions (on natural surface) of four $\mathrm{Cu}^{0}$ particles were analyzed with Particle Induced X-ray Emission (PIXE) and Rutherford Backscattering Spectroscopy (RBS) using $3 \mathrm{MeV} \mathrm{H}^{+}$ions. The ion beam was focused to a rectangular area $(\sim 20 \times 30 \mu \mathrm{m})$ on the particle's surface. PIXE was applied with the aim to obtain the average concentrations of the elements with $\mathrm{Z} \geq 12(\mathrm{Mg})$ and $\mathrm{RBS}$ has been used to obtain concentration depth profiles for the main elements. A Si $(\mathrm{Li})$ detector $\left(80 \mathrm{~mm}^{2}\right)$ was used to detect the X-rays emitted from the sample. The detector was placed outside the sample chamber for easy exchange of absorbers, but necessitating two Be windows with a total thickness of $150 \mu \mathrm{m}$ 
and a $6 \mathrm{~mm}$ air layer. An additional $100 \mu \mathrm{m}$ thick Mylar absorber was used for the PIXE measurements of one sample only [22-216-37-4 (114-117)] whereas the other samples were measured without this absorber. An annular particle detector with a solid angle of about $18 \mathrm{msr}$ was used to detect the backscattered ions. The PIXE spectra were fitted using the program GupixWin (Campbell et al., 2000) and the RBS spectra using the program NDF (Barradas et al., 1997). Nuclear Reaction Analysis (NRA) $\left({ }^{15} \mathrm{~N}\right.$ method; beam spot $\left.\leq 1 \mathrm{~mm}^{2}\right)$ was used to obtain depth profile of $\mathrm{H}$ for one $\mathrm{Cu}^{0}$ specimen [22-216-37-4 (114-117)].

Copper isotope analyses of native $\mathrm{Cu}$ separates and bulk rocks followed previously published methods. The samples were purified by a two stage anion exchange chromatography column using a procedure modified from that of Maréchal et al. (1999), Chapman et al. (2006), Borrok et al. (2007). After a complete digestion step in concentrated $\mathrm{HF}-\mathrm{HNO}_{3}$ and $\mathrm{HCl}-\mathrm{HNO}_{3}$ mixture, bulk rock and $\mathrm{Cu}^{0}$ samples were dissolved in $2 \mathrm{~mL}$ of $6 \mathrm{~mol} / \mathrm{L}$ distilled $\mathrm{HCl}$ in a closed beaker on a hot plate. A precise volume of this solution was then purified using anion exchange chromatography in an $\mathrm{HCl}$ medium (distilled grade). A $5 \mathrm{~mL}$ column was loaded with $1.8 \mathrm{~mL}$ Bio-Rad AG1-X8 anion resin 200 - 400 mesh (chloride form) which was acid cleaned with 10 $\mathrm{mL}$ of $2 \mathrm{~mol} / \mathrm{L} \mathrm{HNO}_{3}, 10 \mathrm{~mL}$ of ultrapure water and $10 \mathrm{~mL}$ of $0.24 \mathrm{~mol} / \mathrm{L} \mathrm{HCl}$ and finally conditioned with $5 \mathrm{~mL}$ of $6 \mathrm{~mol} / \mathrm{L} \mathrm{HCl}$. Under these conditions, $\mathrm{Cu}$ (along with $\mathrm{Fe}$ ) was adsorbed onto the anionic resin while the sample matrix was eluted using $5 \mathrm{~mL}$ of $6 \mathrm{~mol} / \mathrm{L} \mathrm{HCl}$. $\mathrm{Cu}$ was then eluted (and separated from Fe) with $50 \mathrm{~mL}$ of $6 \mathrm{~mol} / \mathrm{L} \mathrm{HCl}$, collected in a PTFE vial and evaporated to dryness. The residue was re-dissolved in $2-3 \mathrm{~mL}$ of $0.28 \mathrm{~mol} / \mathrm{L} \mathrm{HNO}_{3}$ and then further diluted to form a 0.1 to $0.5 \mathrm{ppm} \mathrm{Cu}$ solution ready for isotope analysis. For basalt analysis, this purification step was repeated once as it was found that trace matrix elements and Fe remained in the first $\mathrm{Cu}$ fraction. Quantitative recovery of $\mathrm{Cu}$ through the entire chromatographic procedure was checked by calculating chemistry yield for all samples and also 
by checking $\mathrm{Cu}$ concentration in eluted matrix solution. Yield was found to be systematically better than $98 \%$.

Analyses of ${ }^{65} \mathrm{Cu} /{ }^{63} \mathrm{Cu}$ were carried out on a Thermo-Neptune MC-ICP-MS operating at low resolution. The samples were introduced into the plasma using a double spray quartz spray chamber system (cyclonic and double pass) and a microconcentric PFA nebulizer operating at a flow rate of about $60 \mu \mathrm{L} \mathrm{min}{ }^{-1}$. Instrumental mass bias was corrected for using $\mathrm{Zn}$ isotopes as an internal standard and involves simultaneous measurement of a $\mathrm{Zn}$ standard solution (SRM 3168a Standard Solution). Also a standard bracketing approach, which normalizes the $\mathrm{Cu}$ isotope ratio to the average measured composition of a standard (SRM 976) was carried out before and after each sample. Standard deviation values (1SD) were calculated according to the number of duplicates (N) executed and reported for each sample. Two internal standards, Spex solution and USGS basalt BHVO-2, were processed through the entire chemical procedure and gave $\delta^{65} \mathrm{Cu}$ values of $0.02 \pm 0.06 \%$ and $0.07 \pm 0.06 \%$ ( $2 \mathrm{SD})$, respectively. Purified Spex solution was observed to be indistinguishable from the pure unprocessed solution, whereas basalt BHVO-2 values were similar to values reported elsewhere (Moynier et al., 2010; Moeller et al., 2012). Following the same procedures we analyzed four additional ODP samples (two altered basalts, one deep-sea clay, one Mn-rich chert; Rouxel et al., 2003) for comparison.

We modeled Eh-pH Cu-phase diagrams using the Geochemist's Workbench 8.0 software based on the "thermo_minteq" database. Physical and chemical parameters used in our calculations are discussed in section $\mathbf{5}$.

\section{Results}


The investigated native $\mathrm{Cu}$ particles were recovered from two different types of host rocks: sedimentary and igneous. The $\mathrm{Cu}^{0}$ occurs as veinlets and small flakes scattered in the sedimentary rocks (Holes 105, 364). $\mathrm{Cu}^{0}$ fills vesicles and branching cracks in the igneous basement rocks (Holes 216, 597C, 642E), which upon gentle opening reveal larger (up to c. 10 mm) thin $\mathrm{Cu}^{0}$ leaves (Fig. 2A). Native $\mathrm{Cu}$ particles (Fig. 2B) scattered in the basalts and veins (Fig. 2C) crossing the basalts and sediments are composed of euhedral to subhedral crystals. The most common crystal forms are octahedrons (Fig. 2D) and cubes, which although often being very strongly distorted are recognisable on the surface of the $\mathrm{Cu}^{0}$ leaves (Fig. 2E). The grains display very high metallic lustre on freshly cut surfaces (Fig. 2B, C). The surface colour is a brilliant deep rose-white (Fig. 2B, C), which darkens to „copper-red” and later to red-brown (Fig. $2 \mathrm{~A})$ if the polished surface is not immediately protected.

Reflectance values in air (and oil) from a representative $\mathrm{Cu}^{0}$ grain [22-216-37-4 (114-117)] at the four wavelengths $(470,546,589$ and $650 \mathrm{~nm})$ recommended by the IMA Commission on Ore Minerals are 56.7 (45.0), 64.5 (55.2), 92.0 (86.1), and 97.0 (95.6), respectively. The obtained reflectance spectra compare very well with those listed for native $\mathrm{Cu}$ (Fig. 3) in the Quantitative Data File for Ore Minerals (Criddle and Stanley, 1993).

Vickers microhardness $\left(\mathrm{H}_{\mathrm{v}}\right)$ measurements on polished sections gave average values [22216-37-4 (114-117): $\quad \mathrm{H}_{\mathrm{v}}=65.5 \quad$ (10 measurements); 92-597C-4-1C (33-35): $\mathrm{H}_{\mathrm{v}}=80.5 \quad$ (3 measurements); $92-597 \mathrm{C}-7-316$ (135-138): $\mathrm{H}_{\mathrm{v}}=71.3$ (three measurements)] similar to the data reported on other native $\mathrm{Cu}$ occurrences (Ramdohr, 1980).

XRD investigations of a $\mathrm{Cu}^{0}$ leaf [22-216-37-4 (114-117)] showed characteristic reflections and a unit cell parameter $\left[(h k l), \mathrm{d}_{\text {obs. }}(\AA), \mathrm{d}_{\text {calc. }}(\AA)\right.$, relative intensity (\%): $(111), 2.077,2.084$, $100 ;(200), 1.802,1.804,4 ;(220), 1.276,1.276,75 ;(311), 1.090,1.088,37]\left(a_{0}=3.609 \AA\right)$ comparable to those observed in diffractograms of other native copper samples $[(h k l), d(\AA)$, 
relative intensity (\%): (111), 2.088, 100; (200), 1.808, 46; (220), 1.278, 20; $(311), 1.090,17]$ $\left(a_{0}=3.6150 \AA\right)($ Powder Diffraction File 4-836).

EMP analyses on polished sections native $\mathrm{Cu}$ grains revealed they were almost pure $\mathrm{Cu}$ [22-216-37-4 (114-117): $\mathrm{Cu}=99.3$ wt.\%, average of 5 analyses; 92-597C-4-2D (60-65): $\mathrm{Cu}=98.1$ wt.\%, average of 8 analyses], sometimes with negligible Fe concentration [92-597C-7-3 16 (135138): $\mathrm{Cu}=98.8$ wt.\%, $\mathrm{Fe}=0.14$ wt.\%, average of 9 analyses] and traces of $\mathrm{Sn}$ and $\mathrm{Ca}$ (in a few point analyses).

The mineral phases in visible close association with the $\mathrm{Cu}^{0}$ particles (stuck on their surface) vary in colour from light-blue to turquoise-blue (Fig. 2A). They form masses of fine granules (Fig. 2F) or needle-like crystals (Fig. 2H), clusters of kidney-like grains (Fig. 2G) and aggregates of lamellar crystals (Fig. 2F). According to the EDS studies they are copper oxyhalides $(\mathrm{Cu}, \mathrm{Cl}, \mathrm{O})$ and copper sulphate oxy-chlorides $(\mathrm{Cu}, \mathrm{S}, \mathrm{Cl}, \mathrm{O})$. EMP analyses (three spots) on polished section of these mineral phases [92-597C-4-2D (60-65)] yield an average composition (in wt.\%): $\mathrm{Cu}=85.1, \mathrm{O}=14.2, \mathrm{Cl}=1.37, \mathrm{Fe}=0.02$. PIXE analyses (Table 2) on the natural surfaces of two native $\mathrm{Cu}$ particles are close to the EMP results. However, the $\mathrm{Cl}$ and $\mathrm{Fe}$ contents recorded by PIXE are about an order of magnitude higher, suggesting that the native copper particles are coated with microscopic to submicroscopic surface layers of contrasting composition. The recorded traces of $\mathrm{Si}, \mathrm{Ca}$ and $\mathrm{K}$ (Table 2) might be due to analysis of fine silicate particles adhered to the $\mathrm{Cu}^{0}$ surface, whereas the traces of As and $\mathrm{Mn}$ might reflect presence of these elements in the surface coating. RBS depth profiles at the natural surfaces of two native $\mathrm{Cu}$ grains (Fig. 4A, B) show that this surface film (presumably alteration) has a thickness of 11-16 $\mu \mathrm{m}$ and a complex structure. It can be divided into 2 sub-layers: upper (surficial) and lower (internal). In the upper sub-layer (1-6 $\mu \mathrm{m}) \mathrm{O}$ has the highest concentration whereas $\mathrm{Cu}$ and $\mathrm{Cl}$ have equal content (Fig. $4 \mathrm{~A}, \mathrm{~B})$. In the lower sub-layer $(2-7 \mu \mathrm{m}) \mathrm{Cu}$ is the 
most abundant followed by $\mathrm{O}$ and $\mathrm{Cl}$ (Fig. 4A, B). The transitions upper/lower sub-layers and lower sub-layer/pure $\mathrm{Cu}^{0}$ mark gradual $\mathrm{Cu}$ increase, and $\mathrm{O}$ and $\mathrm{Cl}$ decrease (Fig. 4A, B). At the base of the lower sub-layer of one of the $\mathrm{Cu}^{0}$ particles just above the transition to pure $\mathrm{Cu}^{0}$ there is a $\mathrm{Cu}-\mathrm{O}$ sub-sublayer $(2 \mu \mathrm{m})$ (Fig. 4A). The NRA depth profile of $\mathrm{H}$ for one of these $\mathrm{Cu}^{0}$ particles shows decrease of $\mathrm{H}$ content with increasing depth in the surface film: at $0.5 \mu \mathrm{m}, 23.5$ at. $\% \mathrm{H}$; at $1.0 \mu \mathrm{m}, 16.8$ at.\% $\mathrm{H}$.

The $\mathrm{Cu}$ isotope compositions of the two types of native $\mathrm{Cu}$ occurrences (sedimentary rockhosted and igneous rock-hosted) show different trends (Table 3). Sedimentary rocks that host $\mathrm{Cu}^{0}$ grains have slightly negative $\delta^{65} \mathrm{Cu}$ values $\left(\delta^{65} \mathrm{Cu}_{\text {average }}=-0.13 \%, 1 \mathrm{SD}=0.02 \%, \mathrm{~N}=4\right)$ whereas the $\mathrm{Cu}^{0}$ grains in them show positive $\delta^{65} \mathrm{Cu}$ values $(0.4-1.0 \%$; Table 3$)$. The basalts and native $\mathrm{Cu}$ occurrences in them have slightly positive $(0.0-0.3 \%) \delta^{65} \mathrm{Cu}$ values. However, whereas the Pacific samples (both basalt and native $\mathrm{Cu}$ ) have $\delta^{65} \mathrm{Cu}$ values clustering at $0.0 \%$, the samples from the Indian Ocean show slight enrichment in heavy isotopes with $\delta^{65} \mathrm{Cu}_{\text {basalt }}=0.3 \%$ and $\delta^{65} \mathrm{Cu}_{\text {native } \mathrm{Cu}}=0.1-0.2 \%$ (Table 3$)$. The reference altered basalts $\left(\delta^{65} \mathrm{Cu}_{\text {average }}=0.05 \%\right.$, $1 \mathrm{SD}=$ $0.03 \%, \mathrm{~N}=4)$ and deep-sea clays $\left(\delta^{65} \mathrm{Cu}_{\text {average }}=0.01 \%, 1 \mathrm{SD}=0.02 \%, \mathrm{~N}=4\right)$ from other ODP sites have $\mathrm{Cu}$ isotope compositions close to the average crustal value: $\delta^{65} \mathrm{Cu}=0.0-0.1 \%$ (Table 3).

\section{Discussion}

The studied native $\mathrm{Cu}$ occurrences are hosted in two types of rocks: igneous and sedimentary. These two different geologic associations imply different mechanisms of native $\mathrm{Cu}$ formation and possibly different $\mathrm{Cu}$ sources. In general, $\mathrm{Cu}^{0}$ occurs in a wide variety of environments (basic and ultrabasic igneous rocks, sedimentary rocks and sulfide ores) and 
obviously forms via a range of processes (Cornwall, 1956), which explains the number of genetic models proposed for any particular native $\mathrm{Cu}$ deposit.

\section{1. $C u$ isotope systematic and native $C u$ formation in volcanic basement}

\subsubsection{Primary magmatic origin}

Based on theoretical considerations and experimental studies, it has already been suggested that native $\mathrm{Cu}$ in basalt may have a primary magmatic origin (Hofmeister and Rossman, 1985; Cabral and Beaudoin, 2007). The magmatic origin of $\mathrm{Cu}^{0}$ supposes it has crystallized in equilibrium with the basaltic magma. Investigations of the $\mathrm{Cu}$-isotope composition of primary $\mathrm{Cu}^{0}$ grains in ultramafic rocks (Ikehata and Hirata, 2012) showed homogeneous $\delta^{65} \mathrm{Cu}$ values between -0.03 and $0.14 \%$, implying that there is no significant $\mathrm{Cu}$-isotope fractionation during high-temperature magmatic processes. Studies on magmatic $\mathrm{Cu}^{0}$ (Cabral and Beaudoin, 2007) revealed that it occurs as micrometric $(\sim 50 \mu \mathrm{m})$ inclusions in rock-forming minerals and contains high concentrations of volatile elements $(0.2-2.0 \% \mathrm{~S}$, up to $0.6 \% \mathrm{As})$. However, the native $\mathrm{Cu}$ from Site 597C occurs mainly as vein fillings and does not have EMP detectable ( $\geq 0.1$ wt.\%) content of $\mathrm{S}$ and As. This suggests that these $\mathrm{Cu}^{0}$ occurrences are not primary magmatic although they have $\delta^{65} \mathrm{Cu}$ values close to that of the host basalt $(\sim 0.0 \%$, Table 3$)$.

\subsubsection{Secondary formation through low-temperature in situ alteration of Cu-sulfides}

In seafloor basalts, the primary (magmatic) Cu-mineral is chalcopyrite (Gitlin, 1985). In addition, hydrothermal fluid circulation at mid-oceanic ridges leads to alteration of the basement rocks with precipitation of $\mathrm{Cu}$-sulfides as disseminated mineralization in veins (Dill et al., 1992; Alt, 1995; Teagle and Alt, 2004; Sharkov et al., 2007). Although no evidences of both magmatic 
and hydrothermal $\mathrm{Cu}$-sulfides could be identified throughout the basement section where we studied native $\mathrm{Cu}$, some sections (e.g., of Site 216) clearly show evidence for hydrothermal alteration. Therefore, we cannot theoretically rule out the possibility that native $\mathrm{Cu}$ has formed as secondary product of in situ chalcopyrite alteration.

Supergene alteration of the chalcopyrite $\left(\mathrm{Cu}^{+} \mathrm{Fe}^{3+} \mathrm{S}_{2}{ }^{2-}\right.$; Pearce et al., 2006) may proceed through the following reaction:

$$
2 \mathrm{Cu}^{+} \mathrm{Fe}^{3+} \mathrm{S}_{2}+8 \mathrm{O}_{2(\mathrm{aq})}+2 \mathrm{H}^{+} \leftrightarrow 2 \mathrm{Cu}^{+}+\mathrm{Fe}_{2}\left(\mathrm{SO}_{4}\right)_{3}+\mathrm{H}_{2} \mathrm{SO}_{4}
$$

This reaction goes towards chalcopyrite dissolution as Eh increases and $\mathrm{pH}$ decreases. Released $\mathrm{Cu}^{+}$may further be reduced to $\mathrm{Cu}^{0}$ by the action of ferric sulfate:

$$
\mathrm{Cu}^{+}+\mathrm{Fe}_{2}\left(\mathrm{SO}_{4}\right)_{3}+2 \mathrm{H}^{+}+3 \mathrm{e}^{-} \leftrightarrow \mathrm{Cu}^{0}+2 \mathrm{FeSO}_{4}+\mathrm{H}_{2} \mathrm{SO}_{4}
$$

Although $\mathrm{Cu}$-isotope fractionation factors for reaction 2 are not known from experimental studies, it has generally been considered that native $\mathrm{Cu}$ formation through this process may lead to significant $\mathrm{Cu}$-isotope fractionation (Larson et al., 2003; Ikehata et al., 2011). The direction of $\mathrm{Cu}$-isotope fractionation, however, is unclear. Larson et al. (2003) have suggested that $\mathrm{Cu}^{+}$ reduction to $\mathrm{Cu}^{0}$ in hydrothermal conditions may lead to higher $\mathrm{Cu}$-isotope values during precipitation of native $\mathrm{Cu}$, whereas Ikahata et al. (2011) reported lower $\delta^{65} \mathrm{Cu}$ values for secondary native $\mathrm{Cu}$. In addition, $\mathrm{Cu}$-isotope fractionation may also proceed during the leaching of $\mathrm{Cu}$-sulfides (reaction 1), with a preferential release of heavier $\mathrm{Cu}$-isotope (Rouxel et al., 2004; Kimball et al., 2009). Hence, considering the restricted range of $\mathrm{Cu}$-isotope fractionation in $\mathrm{Cu}^{0}$ recovered in volcanic basement, it is unlikely that native $\mathrm{Cu}$ form during supergene in situ alteration of magmatic and hydrothermal $\mathrm{Cu}$-sulfides.

\subsubsection{Direct precipitation during low-temperature ridge flank fluid circulation}


In addition to the main primary $\mathrm{Cu}$-mineral in seafloor basalts (chalcopyrite) $\mathrm{Cu}$ also occurs as trace element in primary magmatic Fe-sulfides and silicates (e.g., olivine, basaltic glass) in the basement rocks. Seafloor weathering of basaltic glass (palagonitization) results in $\sim 25 \%$ depletion of $\mathrm{Cu}$ relative to the unaltered glass (Ailin-Pyzik and Sommer, 1981). This suggests that low-temperature alteration of the basaltic glass by seawater may be a source of $\mathrm{Cu}$ to the resultant fluid. Therefore, the dissolution of primary minerals (sulfides, olivine) and volcanic glass during basalt alteration by seawater might be considered as a principal process supplying $\mathrm{Cu}$ to the mineralizing fluid. Low-temperature seawater-basalt interaction leads to pervasive oxidation of primary magmatic sulfides (chalcopyrite, pyrrhotite) and breakdown of primary igneous silicates with formation of secondary oxyhydroxides, sulfates and clays (Alt, 1995; Bach and Edwards, 2003). Low-temperature oceanic basement alteration is a ubiquitous process that occurs at vast areas at mid-ocean ridge (MOR) flanks (affects $>1 / 3$ of the seafloor), where convection of seawater in the crust persists for several tens of millions of years (Wheat et al., 2000; 2003). In order to determine whether low-temperature seawater-basalt interactions may lead to the formation of native $\mathrm{Cu}$ in the oceanic basement, we modeled Eh-pH phase diagrams using the compositional parameters of fluids encountered at mid-ocean ridge flank setting. Based on the investigation of the pore fluids extracted from the sediment above the oceanic basement and diffuse vent fluids at the seafloor Wheat and Mottl (2000) and Wheat et al. (2000; 2002) inferred the chemical composition of the basement fluids (formation waters) and chemical fluxes during basement alteration. These fluids are of two types: "cool" $\left(20-25^{\circ} \mathrm{C}\right)$ and "warm" (60$65^{\circ} \mathrm{C}$ ) (Wheat et al., 2003) with $\mathrm{Cu}$ concentrations of 2 and $0.2 \mathrm{nmol} / \mathrm{L}$, respectively. These contents are lower than that of the deep seawater $(5.6 \mathrm{nmol} / \mathrm{L})$ entering the crust and imply that the oceanic crust acts as a sink for $\mathrm{Cu}$ from the seawater. In fact the model of Wheat et al. (2002; 2003) presents data from the beginning (seawater) and end (vent fluid) of the circulation cell. In 
the absence of data for the circulation cell between these two end points, we suppose that a complex scenario forms the basement fluid composition. Therefore, we may speculate that lowtemperature alteration of the oceanic crust supplies $\mathrm{Cu}$ to the basement fluids through breakdown of $\mathrm{Cu}$-containing minerals. Copper leached from the crust dominates over seawater $\mathrm{Cu}$ in the $\mathrm{Cu}$ budget of the basement fluids. During basement fluid circulation major part of dissolved $\mathrm{Cu}$ (leached + seawater $\mathrm{Cu}$ ) reprecipitates in the crust and does not enter the ocean with the "cool" and "warm" vent fluids.

Our initial calculations showed that in the temperature range $20-65^{\circ} \mathrm{C}$ the stability fields of different $\mathrm{Cu}$ species do not change significantly. Therefore, we report the Eh-pH diagrams at $60^{\circ} \mathrm{C}$ (Fig. 5). Since we are not able to estimate the local $\mathrm{Cu}$ concentration in the basement fluids at the point of $\mathrm{Cu}$ leaching from the primary minerals, we have taken the seawater $\mathrm{Cu}$ activity value $\left(\mathrm{a}[\mathrm{Cu}]=5.610^{-9}\right.$, calculated from $\left.[\mathrm{Cu}]=5.6 \mathrm{nmol} / \mathrm{L}\right)$ in our modeling (Fig. 5). The activities of other components used in the modeling $\left(\mathrm{a}[\mathrm{Cl}]=0.55 ; \mathrm{a}[\mathrm{S}]=0.018 ; \mathrm{a}[\mathrm{Fe}]=110^{-9}\right)$ were calculated from their concentrations in the basement fluids reported by Wheat et al. (2010). Since the effect of pressure on the calculations in the relevant range of shallow burial is negligible, all calculations were made under standard state pressure of $1 \mathrm{~atm}$.

The stability fields of $\mathrm{Cu}$ - and Fe-sulfides at low-temperature $\left(20-65^{\circ} \mathrm{C}\right)$ in the oceanic basement (Fig. 5a, b) are controlled by the activity of $\mathrm{H}_{2} \mathrm{~S}$ or $\mathrm{HS}^{-}$(Fig. 5c). $\mathrm{Cu}^{0}$ is stable under low Eh and high $\mathrm{pH}$ conditions when $\mathrm{H}_{2} \mathrm{~S}$ and/or Fe are absent (Eh<-0.25 V; pH>5; Fig. 5a, d, e) and practically cannot exist in the system $\mathrm{Fe}-\mathrm{Cu}-\mathrm{S}$. In anoxic basalt-dominated systems absence of $\mathrm{Fe}^{2+}$ in solution is unlikely, but not the absence of $\mathrm{H}_{2} \mathrm{~S}$. Such conditions may prevail during low-temperature basalt alteration where the dissolution of olivine and volcanic glass at low water/rock ratios generate $\mathrm{Fe}^{2+}$ in solution without thermogenic seawater sulfate reduction (Seyfried and Bischoff, 1979). Fig. 5e is calculated for such a system. It is important to note that 
every increase in $\mathrm{a}[\mathrm{Cu}]$ or a decrease of $\mathrm{a}[\mathrm{Cl}]$ will expand the stability field of the $\mathrm{Cu}^{0}$. When $\mathrm{H}_{2} \mathrm{~S}$ is present (Fig. 5a) and assuming $\mathrm{H}_{2} \mathrm{~S}_{\mathrm{SO}} \mathrm{S}_{4}$ equilibrium conditions, $\mathrm{Cu}$-sulfide minerals become more dominant in the low Eh range and the stability field of $\mathrm{Cu}^{0}$ shrinks to relatively basic $(\mathrm{pH}>9)$ conditions, or completely disappears when $\mathrm{Fe}^{2+}$ is present in solution (Fig. 5b).

Since the stability field of the $\mathrm{Cu}^{0}$ overlaps with the stability field of $\mathrm{Cu}^{+}$species, it is assumed that $\mathrm{Cu}^{0}$ is precipitated directly from $\mathrm{Cu}^{+}$species in such reaction:

$$
4 \mathrm{CuCl}_{2}^{-}+2 \mathrm{H}_{2} \mathrm{O} \leftrightarrow 4 \mathrm{H}^{+}+\mathrm{O}_{2 \mathrm{aq}}+4 \mathrm{Cu}_{\text {metal }}^{0}+8 \mathrm{Cl}^{-}
$$

Copper isotope fractionation factors for such a reaction are not known (Fujii et al., 2013). Because reduction of metals typically produces negative fractionations (Ellis et al., 2002; Ehrlich et al., 2004; Tossell, 2005), similar fractionation trend could be expected for the process of $\mathrm{Cu}^{0}$ precipitation from $\mathrm{Cu}^{+}$-bearing solution (Reaction 3).

Basalts and $\mathrm{Cu}^{0}$ from Sites 216 and 597C show $\delta^{65} \mathrm{Cu}$ values of 0.30 and $0.07 \%$, and 0.14 0.19 and $0.02 \%$, respectively (Table 3 ). The fact that all basalt samples fall within the igneous rocks $\delta^{65} \mathrm{Cu}$ range [ $\sim \%$ o (Zhu et al., 2000; Larson et al., 2003; Mason et al., 2005; Mathur et al., 2005; Asael et al., 2007; Moynier et al., 2010; Moeller et al., 2012)] shows that no significant processes of $\mathrm{Cu}$-isotope fractionation occurred in them during and after the formation of the $\mathrm{Cu}^{0}$, probably due to the fact that bulk $\mathrm{Cu}$ concentration in the rocks is not greatly affected by alteration processes. $\mathrm{Cu}$-isotope composition of altered basalts from ODP Sites 801 and 1149 (Table 3) also confirm the lack of Cu-isotope fractionation during seafloor weathering.

At Site 216, the host basalt is anomalously enriched in $\mathrm{Cu}([\mathrm{Cu}]>2000 \mathrm{ppm})$, but this enrichment is probably due to disseminated $\mathrm{Cu}^{0}$ grains within the rock groundmass. The fact that significant quantity of $\mathrm{Cu}$ is found enriched in veins and even in bulk rock suggests that $\mathrm{Cu}$ should have been mobilized from large volume of volcanic rock before being concentrated 
locally. This requires considerable migration of $\mathrm{Cu}$-bearing solutions together with an efficient trapping mechanism.

In the altered oceanic crust, the buffered $\mathrm{pH}$ conditions due to seawater/rock reactions, low Eh due to $\mathrm{Fe}^{2+}$ release from the basalt and absence of sulfate reduction would result in conditions suitable for $\mathrm{Cu}^{0}$ precipitation (Fig. 5). Cu-bearing solutions within the oceanic crust are likely to form during low-temperature alteration of basement rocks through interaction with seawater and breakdown of $\mathrm{Cu}$-containing minerals. Although Wheat et al. (2002; 2003) suggested that oceanic crust alteration via interaction with seawater may provide a net sink of seawater $\mathrm{Cu}$, our $\mathrm{Cu}$-isotope data for native $\mathrm{Cu}$ argue against a seawater origin of $\mathrm{Cu}$, since $(1) \delta^{65} \mathrm{Cu}_{\text {seawater }}=+0.8$ - +1.5\% (Vance et al., 2008; Takano et al., 2013; Thompson et al., 2013) and (2) reduction of $\mathrm{Cu}^{2+}$, which is the main redox $\mathrm{Cu}$ species in seawater, to $\mathrm{Cu}^{+}$and ultimately to $\mathrm{Cu}^{0}$ would produce large range of $\mathrm{Cu}$-isotope composition depending on the extent of reduction (Ehrlich et al., 2004; Mathur et al., 2005). Hence, the limited Cu-isotope fractionation found in basalt-hosted $\mathrm{Cu}^{0}$ has likely resulted from the transport of $\mathrm{Cu}$ mainly as $\mathrm{Cu}^{+}$species. It also suggests limited $\mathrm{Cu}$-isotope fractionation during $\mathrm{Cu}$ leaching from the basement rocks (e.g., glass, sulfides and silicates).

Finally, we suggest that the $\mathrm{Cu}^{0}$ occurrences in the basalts can only form under low a[Cu] and $\mathrm{H}_{2} \mathrm{~S}$ conditions precluding the precipitation of $\mathrm{Cu}^{+}$-secondary minerals. The precipitation of $\mathrm{Cu}^{0}$ would have proceeded over protracted periods as the alteration fluids (basement fluids) circulate through basalt fractures. It is further possible that $\mathrm{Cu}^{0}$ precipitation in veins has resulted from autocatalytic reaction or at specific redox front within the rock under low Eh condition and where $\mathrm{H}_{2} \mathrm{~S}$ is absent or very low.

\subsection{Isotope constraints of $\mathrm{Cu}$ source and native $\mathrm{Cu}$ formation in marine sediments}


Sedimentary rocks hosting native $\mathrm{Cu}$ at Sites 105 (clayey reddish-brown limestone) and 364 (yellowish brown pelagic clay) have slightly negative $\delta^{65} \mathrm{Cu}$ values $(-0.06$ and $-0.19 \%$, respectively) that differ from that of the average deep-sea clays $(0.01 \%)$ (Table 3$)$. However, the $\mathrm{Cu}^{0}$ occurrences in them show heavier $\mathrm{Cu}$-isotope composition: $0.41-0.49 \%$ and $0.95 \%$, respectively.

At Site 105, native $\mathrm{Cu}$ is located within well lithified red clayey limestones $\sim 10 \mathrm{~m}$ above the basement. The red color of the host rocks is due to hematite staining (Lancelot et al., 1972) that may have been derived from Fe-oxyhydroxides syngenetically precipitated from seawater as a result of hydrothermal input. Hence, the $\mathrm{Cu}$ source in these sedimentary rocks might be related to seafloor hydrothermal activity such as plume fallout containing $\mathrm{Cu}$-sulfides [chalcopyrite, cubanite, covellite; Mottl and McConachy (1990)].

At Site 364, native $\mathrm{Cu}$ is located within a thick sediment layer of marly ooze and pelagic clay, $3000 \mathrm{~m}$ above the sediment/basement interface. Although the ultimate $\mathrm{Cu}$ source is unclear, $\mathrm{Cu}$ enrichment is likely authigenic: either through direct $\mathrm{Cu}$ precipitation from seawater (co-precipitation with Fe-Mn-oxyhydroxides or adsorbed on them; i.e., hydrogenetic), oxidation of organic matter, or eventually from hydrothermal plume fallout $\left(\mathrm{Cu}\right.$-sulfides or $\mathrm{Cu}^{2+}$ scavenged from seawater by Fe-oxyhydroxides). The lack of $\mathrm{Mn}$ and $\mathrm{Ni}$ enrichment associated with $\mathrm{Cu}^{0}$ occurrence requires specific diagenetic reactions that would explain both the precipitation of $\mathrm{Cu}^{0}$ and lack of other metal enrichments that are typical of hydrogeneous precipitates.

It is important to note that seawater shows positive $\delta^{65} \mathrm{Cu}$ values: $0.8-1.5 \%$ (Bermin et al., 2006; Vance et al., 2008; Takano et al., 2013; Thompson et al., 2013). Hydrogeneous Mn-Feoxyhydroxide nodules are also characterized by positive $\delta^{65} \mathrm{Cu}$ values: $0.1-0.6 \%$ (Albarède, 2004). In addition, experimental studies of $\mathrm{Cu}^{2+}$ adsorption onto amorphous $\mathrm{Fe}^{3+}$-oxyhydroxides 
suggest an enrichment of heavy $\mathrm{Cu}$ isotope in the solid phase (Balistrieri et al., 2008; Pokrovsky et al., 2008). Hence, from an isotopic point of view, seawater is a likely $\mathrm{Cu}$ source for the $\mathrm{Cu}^{0}$ occurrence in the sediments. A two-stage process may explain both positive $\delta^{65} \mathrm{Cu}$ values and native $\mathrm{Cu}$ formation. First, hydrogeneous and/or hydrothermal enrichment of $\mathrm{Cu}$ through adsorption onto $\mathrm{Mn}-\mathrm{Fe}$-oxyhydroxides leads to the formation of isotopically heavy $\mathrm{Cu}$ reservoir in the sediment. During early diagenetic remineralization of organic matter in the sediment, anaerobic microbial respiration would reduce $\mathrm{Mn}$ - and Fe-oxyhydroxides and result in a net loss of those metals (and others) to the seawater/sediment interface. Organic matter remineralization through microbial processes may also provide reduction mechanisms to generate $\mathrm{Cu}^{0}$ from $\mathrm{Cu}^{2+}$. In that case, complete reduction of $\mathrm{Cu}^{2+}$ to $\mathrm{Cu}^{0}$ would preserve its original isotope signature, which is in this case characterized by positive $\delta^{65} \mathrm{Cu}$ values. The relatively low concentrations of organic matter at Sites 105 and 364 would also result in very limited sulfate reduction in porewaters, therefore precluding the precipitation of $\mathrm{Fe}-\mathrm{Cu}$-sulfides instead of native $\mathrm{Cu}$.

$\mathrm{Cu}$-isotope data for the visible bluish phases on the $\mathrm{Cu}^{0}$ surfaces $\left(\delta^{65} \mathrm{Cu}_{\text {bluish phase }}<\right.$ $\delta^{65} \mathrm{Cu}_{\text {native Cu}}$; Table 3) may give further clues to their origin. The composition (EMP data on polished section) of these phases is close to those of atacamite and paratacamite. Whereas some native $\mathrm{Cu}$ particles had such minerals visibly stuck on their surfaces other $\mathrm{Cu}^{0}$ grains exhibited clear surfaces without any visible mineral phases on them. With PIXE we targeted this type of clear surfaces of native $\mathrm{Cu}$ particles and likely the PIXE data represent the composition of a thin, surface alteration film of $\mathrm{Cu}^{0}$. The visible mineral phases (EMP analyses) on the $\mathrm{Cu}^{0}$ surfaces may form not only as alteration products, but might also be minerals precipitated contemporarily or after the $\mathrm{Cu}^{0}$ formation. Although the composition of the surface film of $\mathrm{Cu}^{0}$ particles (PIXE data) does not match precisely the composition of any mineral phase, these data along with the 
RBS and NRA depth profiles suggest that the surface alteration film is composed of phases very close to atacamite and paratacamite. This sounds reasonable in view of stability and mode of formation of these minerals at seafloor conditions (Hannington, 1993). The complex structure of this surface film (composed of sub-layers of different composition) implies that the alteration of native $\mathrm{Cu}$ at seafloor conditions is a process dependant on the kinetics of reactions of $\mathrm{Cu}^{0}$ with pore fluid $\mathrm{O}_{2}$ and $\mathrm{Cl}^{-}$. The composition of the surface film sub-layers suggests an evolution of the alteration phase from oxygen-dominated copper oxy-chloride (surficial sub-layer) towards atacamite/paratacamite-like phase (internal sub-layer).

The $\delta^{65} \mathrm{Cu}$ values of the bluish $\mathrm{Cu}^{2+}$-phases around the $\mathrm{Cu}^{0}$ grains are between those of the host rock and of the $\mathrm{Cu}^{0}$. Oxidation of $\mathrm{Cu}$ is accompanied by positive isotope fractionation (Rouxel et al., 2004; Mathur et al., 2005; Asael et al., 2007). A simple oxidation process of the $\mathrm{Cu}^{0}$ grains can explain the fact that the isotopic composition of the $\mathrm{Cu}^{2+}$-phases is heavier with respect to the $\mathrm{Cu}^{0}$ grains. Precipitation of atacamite and paratacamite $\left(\mathrm{Cu}^{2+}\right.$-minerals that compose the bluish phases) requires $\mathrm{a}[\mathrm{Cu}]$ values in the solution which are at least an order of magnitude higher than that necessary for $\mathrm{Cu}^{0}$ precipitation (Eh-pH phase diagram not shown). In addition, $\mathrm{OH}^{-}$should also be available in the system. Hence, the most likely source for the high $\mathrm{a}[\mathrm{Cu}]$ values in the fluid is local partial re-dissolution of the $\mathrm{Cu}^{0}$ grains.

\subsection{Comparison with economic-size native $\mathrm{Cu}$ deposits}

Native $\mathrm{Cu}$ deposits are amongst the most important $\mathrm{Cu}$ resources (e.g., Wang et al., 2006; Cooper et al., 2008; Pinto et al., 2011). Generally, they are interpreted to be genetically related to the associated magmatic rocks despite the low $\mathrm{Cu}$ concentrations in magmatic systems (Cornwall, 1956; Amstutz, 1977). A major question that remains debatable is the mechanism that effectively 
mobilizes $\mathrm{Cu}$ from a $\mathrm{Cu}$-poor matrix and eventually concentrates it in economic grades. Therefore, it is not surprising that a number of scenarios have been proposed for the origin of native $\mathrm{Cu}$ deposits (e.g., Cornwall, 1956; Brown, 2006). A general issue of all the genetic models is that a detailed investigation of the mechanisms of $\mathrm{Cu}$ mobilization, concentration and deposition is limited because once the $\mathrm{Cu}$-deposit has formed pre-ore host-rock $\mathrm{Cu}$ contents and concentration mechanisms are no longer accessible. Later processes additionally obscure the situation and complicate the deciphering of the original conditions. Therefore, $\mathrm{Cu}^{0}$ occurrences disseminated in the oceanic crust present an opportunity to investigate $\mathrm{Cu}$-isotope signatures of native $\mathrm{Cu}$ in a pre-ore setting and to eventually use them in further genetic models of native $\mathrm{Cu}$ deposits.

In this context it would be interesting to compare the $\mathrm{Cu}$-isotope composition of $\mathrm{Cu}^{0}$ from the oceanic crust with that of $\mathrm{Cu}^{0}$ from the native $\mathrm{Cu}$ deposits. Copper isotope composition of native $\mathrm{Cu}$ occurrences from continental ore deposits (Table 4) shows a range of $\sim 5 \%$ : $\delta^{65} \mathrm{Cu}=-$ $3.03-+2.0 \%$. The broadest range of $\mathrm{Cu}$-isotope variations is for supergene $\mathrm{Cu}^{0}\left(\delta^{65} \mathrm{Cu}=-3.03-\right.$ $+1.71 \%$ ), whereas the hydrothermal $\mathrm{Cu}^{0}$ exhibits less $\mathrm{Cu}$-isotope variations $\left(\delta^{65} \mathrm{Cu}=-1.3-\right.$ $+1.25 \%$ ) (Table 4). There is no clear isotopic difference between different genetic types of native $\mathrm{Cu}$. Native $\mathrm{Cu}$ from the oceanic crust (Table 3) shows only positive $\mathrm{Cu}$-isotope values $\left(\delta^{65} \mathrm{Cu}=\right.$ $0.02-0.95 \%$ ) and a much narrower range of $\mathrm{Cu}$-isotope variation. Our data (Table 3) and interpretations also show that $\mathrm{Cu}^{0}$ of similar $\mathrm{Cu}$-isotope composition may have different modes of formation. Another important finding of our study is that the restricted range of $\delta^{65} \mathrm{Cu}_{\text {native } \mathrm{Cu}}$ clustered around igneous rocks isotope values does not necessarily mean a primary (magmatic) origin of $\mathrm{Cu}^{0}$.

\section{Conclusions}


Precipitation of native $\mathrm{Cu}$ is a minor yet ubiquitous process in the sedimentary and igneous sections of the oceanic crust. Using $\mathrm{Cu}$ isotope systematic, we showed that primary magmatic $\mathrm{Cu}$-containing minerals (sulfides, silicates, volcanic glass), hydrothermal $\mathrm{Cu}$-sulfides and seawater were potential sources of $\mathrm{Cu}$ in this environment. Overall, within the basaltic basement, $\mathrm{Cu}$ dissolution and $\mathrm{Cu}^{0}$ precipitation occurred in conditions where $\mathrm{Cu}^{+}$-species were dominant, $\mathrm{Cu}$ redox fractionation did not take place and this resulted in relatively small $\mathrm{Cu}$-isotope variations. On the other hand, it seems that the larger $\mathrm{Cu}$-isotope variations observed in the $\mathrm{Cu}^{0}$ in the sedimentary rocks reflect solutions, which were generally dominated by seawater-derived $\mathrm{Cu}^{2+}$-species that underwent redox processes during the diagenesis leading to precipitation of $\mathrm{Cu}^{0}$ with larger $\mathrm{Cu}$-isotope fractionation.

$\mathrm{Cu}^{0}$ formation in the basaltic basement is related to seawater-rock interaction at ridge flank setting that results in low-temperature $\left(20^{\circ}-65^{\circ} \mathrm{C}\right)$ hydrothermal activity (Fig. 6). Following the model by Wheat et al. (2002) we presume that cold and oxic seawater enters the crust at MOR crest, alters (warms and becomes anoxic) during its flow within the crust and vents out the seafloor (at discharge zones). Evidences suggest that the basement fluid may progressively loose only a small fraction of $\mathrm{SO}_{4}{ }^{2-}$ as a result of diffusive exchange with the overlying anoxic and organic-rich sediment (cf. Elderfield et al., 1999) or microbial sulfate reduction (Rouxel et al., 2008; Ono et al., 2011). The evolving anoxic, but $\mathrm{H}_{2} \mathrm{~S}$-deficient fluid creates favorable conditions for $\mathrm{Cu}$ discharge and $\mathrm{Cu}^{0}$ precipitation. Sediment cover receives major $\mathrm{Cu}$ contribution from hydrogenous and hydrothermal (plume fallout) sources. Disseminated hydrogenous and/or hydrothermal $\mathrm{Cu}$ might be diagenetically remobilized and eventually reprecipitated as $\mathrm{Cu}^{0}$ in reducing microenvironment. 
Although the $\mathrm{Cu}^{0}$ occurrences in the oceanic crust are unusual they apparently are not very rare. The fact that they are rarely reported in the DSDP/ODP cores likely means that they may have often been overlooked. Despite the scarcity and microscopic scale of $\mathrm{Cu}^{0}$ occurrences the results of our investigation gave some clues on $\mathrm{Cu}$ sources and $\mathrm{Cu}^{0}$ deposition at an early stage before its concentration in large deposits of economic grade.

Several major questions remain open for future studies: (1) what are the $\mathrm{Cu}$ fractionation factors during $\mathrm{Cu}^{0}$ precipitation and $\mathrm{Cu}^{0}$ oxidation (to be theoretically and experimentally tackled); (2) what proportion of $\mathrm{Cu}$ is as $\mathrm{Cu}^{0}$ in the host rock, what is the $\mathrm{Cu}$ redox budget $\left(\mathrm{Cu}^{0}\right.$ : $\mathrm{Cu}^{+}: \mathrm{Cu}^{2+}$ ) of the rocks and which minerals host $\mathrm{Cu}^{+}$and $\mathrm{Cu}^{2+}$; (3) is the oceanic crust sink or source of $\mathrm{Cu}$ for the overlaying ocean, or it has a dual function (sink and source); (4) can the insights gained might be extrapolated to other metals, which show similar geochemical behavior: e.g., $\mathrm{Zn}$ and its rare occurrence as native Zn (Clark and Sillitoe, 1970)?

\section{Acknowledgements}

We express our gratitude to the IODP for providing the sample material. This study was supported by AIM (Centre for Application of Ion Beams to Materials Research, Research Infrastructures Transnational Access Contract \#025646), WHOI Mary Sears program (\#27002735), SYNTHESYS (grant SE-TAF-4976; EC Research Infrastructure Action, FP6 Structuring the European Research Area) and Marie Curie Intra European Fellowship (7th European Community Framework Programme; grant \#253182, IsoBAB) grants, which are greatly appreciated. This article has been much improved following the reviews by R. Mathur and D. Canil. 


\section{References}

Abrajano, T.A., Pasteris, J.D., 1989. Zambales ophiolite, Philippines. II. Sulfide petrology of the critical zone of the Acoje Massif. Contrib. Mineral. Petrol. 103, 64-77.

Ailin-Pyzik, I.B., Sommer, S.E., 1981. Microscale chemical effects of low temperature alteration of DSDP basaltic glasses. J. Geophys. Res. 86 (B10), 9503-9510.

Albarède, F., 2004. The stable isotope geochemistry of copper and zinc. Rev. Mineral. Geochem. 55, $409-427$.

Alt, J.C., 1995. Sulfur isotopic profile through the oceanic crust: Sulfur mobility and seawater-crustal sulfur exchange during hydrothermal alteration. Geology 23, 585-588.

Amstutz, G.C., 1977. Time- and strata-bound features of the Michigan copper deposits (USA). In: Klemm, D.D., Schneider, H.-J., (Eds.), Time- and Strata-Bound Ore Deposits, Springer, Berlin-Heidelberg, 123-140.

Anbar, A.D., Rouxel, O., 2007. Metal stable isotopes in paleoceanography. Annu. Rev. Earth Planet. Sci. 35, 717746.

Asael, D., Matthews, A., Bar-Matthews, M., Halicz, L., 2007. Copper isotope fractionation in sedimentary copper mineralization (Timna Valley, Israel). Chem. Geol. 243, 238-254.

Asael, D., Matthews, A., Oszczepalski, S., Bar-Matthews, M., Halicz, L., 2009. Fluid speciation controls of low temperature copper isotope fractionation applied to the Kupferschiefer and Timna ore deposits. Chem. Geol. $262,147-158$.

Bach, W., Edwards, K.J., 2003. Iron and sulfide oxidation within the basaltic ocean crust: Implications for chemolithoautotrophic microbial biomass production. Geochim. Cosmochim. Acta 67, 3871-3887.

Bai, W., Robinson, P.T., Fang, Q., Yang, J., Yan, B., Zhang, Z., Hu, X.-F., Zhou, M.-F., Malpas, J., 2000. The PGE and base-metal alloys in the podiform chromitites of the Luobusa ophiolite, southern Tibet. Can. Mineral. 38, 585-598.

Balistrieri, L.S., Borrok, D.M., Wanty, R.B., Ridley, W.I., 2008. Fractionation of Cu and Zn isotopes during adsorption onto amorphous Fe(III) oxyhydroxide: Experimental mixing of acid rock drainage and ambient river water. Geochim. Cosmochim. Acta 72, 311-328. 
Barradas, N.P., Jeynes, C., Webb, R.P., 1997. Simulated annealing analysis of Rutherford backscattering data. Appl. Phys. Lett. 71, 291-293.

Berger, W.H., von Rad, U., 1972. Cretaceous and Cenozoic sediments from the Atlantic Ocean. In: Hayes, D.E., Pimm, A.C., et al. (Eds.), Init. Repts. DSDP. Washington (U.S. Govt. Printing Office), 14, 787-954.

Bermin, J., Vance, D., Archer, C., Statham, P., 2006. The determination of the isotopic composition of Cu and Zn in seawater. Chem. Geol. 226, 280-297.

Bolli, H.M., Ryan, W.B.F., Foresman, J.B., Hottman, W.E., Longoria, J.F., McKnight, B.K., Natland, J., ProtoDecima, F., Siesser, W.G., 1978. Angola Continental Margin-Sites 364 and 365. In: Bolli, H.M., Ryan, W.B.F., et al. (Eds.), Init. Repts. DSDP. Washington (U.S. Govt. Printing Office), 40, 357-455.

Borrok, D., Wanty, R.B., Ridley, W.I., Wolf, R., Lamothe, P.J., Adams, M., 2007. Separation of copper, iron, and zinc from complex aqueous solutions for isotopic measurement. Chem. Geol. 242, 400-414.

Borrok, D., Nimick, D., Wanty, R., Ridley, W., 2008. Isotopic variations of dissolved copper and zinc in stream waters affected by historical mining. Geochim. Cosmochim. Acta 72, 329-344.

Bougault, H., 1974. Distribution of first series transition metals in rocks recovered during DSDP Leg 22 in the northeastern Indian Ocean. In: von der Borch, C.C., Sclater, J.G., et al. (Eds.), Init. Repts. DSDP. Washington (U.S. Govt. Printing Office), 22, 213-265.

Brown, A.C., 2006. Genesis of native copper lodes in the Keweenaw district, northern Michigan: A hybrid evolved meteoric and metamorphogenic model. Econ. Geol. 101, 1437-1444.

Cabral, A.R., Beaudoin, G., 2007. Volcanic red-bed copper mineralisation related to submarine basalt alteration, Mont Alexandre, Quebec Appalachians, Canada. Miner. Deposita 42, 901-912.

Campbell, J.L., Hopman, T.L., Maxwell, J.A., Nejedly, Z., 2000. The Guelph PIXE software package III: Alternative proton database. Nucl. Instrum. Meth. B 170, 193-204.

Chapman, J.B., Mason, T.F.D., Weiss, D.J., Coles, B.J., Wilkinson, J.J., 2006. Chemical separation and isotopic variations of $\mathrm{Cu}$ and $\mathrm{Zn}$ from five geological reference materials. Geostand. Geoanal. Res. 30, 1-12.

Clark, A.N., Sillitoe, R.H., 1970. Native zinc and $\alpha-\mathrm{Cu}, \mathrm{Zn}$ from mina Dulcinea de Llampos, Copiapó, Chile. Am. Mineral. 55, 1019-1021. 
Cooper, H.K., Duke, M.J.M., Simonetti, A., Chen, G.C., 2008. Trace element and Pb isotope provenance analyses of native copper in northwestern North America: results of a recent pilot study using INAA, ICP-MS, and LAMC-ICP-MS. J. Archaeol. Sci. 35, 1732-1747.

Cornwall, H.R., 1956. A summary of ideas on the origin of native copper deposits. Econ. Geol. 51, 615-631.

Cowen, J.P., Giovannoni, S.J., Kenig, F., Johnson, H.P., Butterfield, D.A., Rappe, M.S., Hutnak, M., Lam, P., 2003. Fluids from aging ocean crust that support microbial life. Science 299, 120-123.

Criddle, A.J., Stanley, C.J., 1993. Quantitative Data File for Ore Minerals, 3rd ed. Chapman and Hall, London.

Dekov, V.M., Damyanov, Z.K., Kamenov, G.D., Bonev, I.K., Bogdanov, K.B., 1999. Native copper and $\alpha-c o p p e r-$ zinc in sediments from the TAG hydrothermal field (Mid-Atlantic Ridge, $26^{\circ} \mathrm{N}$ ): nature and origin. Mar. Geol. $161,229-245$.

Dill, H.G., Gauert, C., Holler, G., Marchig, V., 1992. Hydrothermal alteration and mineralization of basalts from the spreading zone of the East Pacific Rise $\left(7^{\circ} \mathrm{S}-23^{\circ} \mathrm{S}\right)$. Geologische Rundschau 81, 717-728.

Edwards, K.J., Bach, W., Rogers, D., 2003. Geomicrobiology of the ocean crust: A role for chemoautotrophic Febacteria. Biol. Bull. 204, 180-185.

Ehrlich, S., Butler, I., Halicz, L., Rickard, D., Oldroyd, A., Matthews, A., 2004. Experimental study of the copper isotope fractionation between aqueous $\mathrm{Cu}(\mathrm{II})$ and covellite, CuS. Chem. Geol. 209, 259-269.

Elderfield, H., Wheat, C.G., Mottl, M.J., Monnin, C., Spiro, B., 1999. Fluid and geochemical transport through oceanic crust: A transect across the eastern flank of the Juan de Fuca Ridge. Earth Planet. Sci. Lett. 172, 151169.

Eldholm, O., Thiede, J., Taylor, E., Barton, C., Bjørklund, K., Bleil, U., Ciesielski, P., Desprairies, A., Donnally, D., Froget, C., Henrich, R., Jansen, E., Krissek, L., Kvenvolden, K., LeHuray, A., Love, D., Lysne, P., McDonald, T., Mudie, P., Osterman, L., Parson, L., Phillips, J., Pittenger, A., Qvale, G., Schöharting, G., Viereck, L., 1987. Site 642: Norwegian Sea. In: Eldholm, O., Thiede, J., Taylor, E., (Eds.), Proc. Init. Repts. (Pt. A), ODP. 104, 53-453.

Ellis, A.S., Johnson, T.M., Bullen, T.D., 2002. Chromium isotopes and the fate of hexavalent chromium in the environment. Science 295, 2060-2062.

Erzinger, J., 1986. Basement geochemistry, Leg 92. In: Leinen, M., Rea, D.K., et al. (Eds.), Init. Repts. DSDP. Washington (U.S. Govt. Printing Office), 92, 471-480. 
Fisher, A.T., Becker, K., 2000. Channelized fluid flow in oceanic crust reconciles heat-flow and permeability data. Nature 403, 71-74.

Fisk, M.R., Giovannoni, S.J., Thorseth, I.H., 1998. The extent of microbial life in volcanic crust of the ocean basins. Science 281, 978-980.

Fujii, T., Moynier, F., Abe, M., Nemoto, K., Albarède, F., 2013. Copper isotope fractionation between aqueous compounds relevant to low temperature geochemistry and biology. Geochim. Cosmochim. Acta 110, 29-44.

Furnes, H., Staudigel, H., 1999. Biological mediation in ocean crust alteration: How deep is the deep biosphere. Earth Planet. Sci. Lett. 166, 97-103.

Gitlin, E., 1985. Sulfide remobilization during low temperature alteration of seafloor basalt. Geochim. Cosmochim. Acta 49, 1567-1579.

Gold, T., 1992. The deep, hot biosphere. Proc. Natl. Acad. Sci. USA 89, 6045-6049.

Graham, S., Pearson, N., Jackson, S., Griffin, W., O’Reilly, S.Y., 2004. Tracing Cu and Fe from source to porphyry: in situ determination of $\mathrm{Cu}$ and $\mathrm{Fe}$ isotope ratios in sulfides from the Grasberg $\mathrm{Cu}-\mathrm{Au}$ deposit. Chem. Geol. 207, 147-169.

Hannington, M.D., 1993. The formation of atacamite during weathering of sulfides on the modern seafloor. Can. Mineral. 31, 945-956.

Hannington, M.D., Thompson, G., Rona, P.A., Scott, S.D., 1988. Gold and native copper in supergene sulfides from the Mid-Atlantic Ridge. Nature 333, 64-66.

Hayes, D.E., Pimm, A.C., Beckmann, J.P., Benson, W.E., Berger, W.H., Roth, P.H., Supko, P.R., von Rad, U., 1972. Site 141. In: Hayes, D.E., Pimm, A.C., et al. (Eds.), Init. Repts. DSDP. Washington (U.S. Govt. Printing Office), 14, 217-247.

Hekinian, R., 1974. Petrology of igneous rocks from Leg 22 in the northeastern Indian Ocean. In: von der Borch, C.C., Sclater, J.G., et al. (Eds.), Init. Repts. DSDP. Washington (U.S. Govt. Printing Office), 22, $213-265$.

Hofmeister, A.M., Rossman, G.R., 1985. Exsolution of metallic copper from Lake County labradorite. Geology 13, 644-647.

Hollister, C.D., Ewing, J.I., Habib, D., Hathaway, J.C., Lancelot, Y., Luterbacher, H., Paulus, F.J., Poag, C.W., Wilcoxon, J.A., Worstell, P., 1972. Site 105: Lower continental rise hills. In: Hollister, C.D., Ewing, J.I., et al. (Eds.), Init. Repts. DSDP. Washington (U.S. Govt. Printing Office), 11, 219-312. 
Ikehata, K., Hirata, T., 2012. Copper isotope characteristics of copper-rich minerals from the Horoman peridotite complex, Hokkaido, northern Japan. Econ. Geol. 107, 1489-1497.

Ikehata, K., Notsu, K., Hirata, T., 2008. In situ determination of $\mathrm{Cu}$ isotope ratios in copper-rich materials by NIR femtosecond LA-MC-ICP-MS. J. Anal. At. Spectrom. 23, 1003-1008.

Ikehata, K., Notsu, K., Hirata, T., 2011. Copper isotope characteristics of copper-rich minerals from Besshi-type volcanogenic massive sulfide deposits, Japan, determined using a femtosecond LA-MC-ICP-MS. Econ. Geol. $106,307-316$.

Jenkyns, H.C., 1976. Sediments and sedimentary history of the Manihiki Plateau, south Pacific Ocean. In: Schlanger, S.O., Jackson, E.D., et al. (Eds.), Init. Repts. DSDP. Washington (U.S. Govt. Printing Office), 33, 873-890.

Johnson, C.M., Beard, B.L., Albarède, F., 2004. Geochemistry of Non-traditional Stable Isotopes. Reviews in Mineralogy and Geochemistry. Mineralogical Society of America; St. Louis, Washington.

Kennett, J.P., Houtz, R.E., Shipboard Scientific Party, 1975. Site 282. In: Kennett, J.P., Houtz, R.E., et al. (Eds.), Init. Repts. DSDP. Washington (U.S. Govt. Printing Office), 29, 317-363.

Kimball, B.E., Mathur, R., Dohnalkova, C., Wall, J., Runkel, R.L., Brantley, S.L., 2009. Copper isotope fractionation in acid mine drainage. Geochim. Cosmochim. Acta 73, 1247-1263.

Knox, R.W.O’B., 1985. Note on the occurrence of native copper in Tertiary nannofossil oozes from the Goban Spur (Hole 550). In: de Graciansky, P.C., Poag, C.W., et al. (Eds.), Init. Repts. DSDP. Washington (U.S. Govt. Printing Office), 80 (2), 851-852.

Lancelot, Y., Hathaway, J.C., Hollister, C.D., 1972. Lithology of sediments from the western north Atlantic Leg 11 Deep Sea Drilling Project. In: Hollister, C.D., Ewing, J.I., et al. (Eds.), Init. Repts. DSDP. Washington (U.S. Govt. Printing Office), 11, 901-949.

Larson, P.B., Maher, K., Ramos, F.C., Chang, Z., Gaspar, M., Meinert, L.D., 2003. Copper isotope ratios in magmatic and hydrothermal ore-forming environments. Chem. Geol. 201, 337-350.

LeHuray, A.P., 1989. Native copper in ODP Site 642 tholeiites. In: Eldholm, O., Thiede, J., Taylor, E., et al. (Eds.), Proc. ODP, Sci. Results. College Station, TX (Ocean Drilling Program), 104, 411-417.

Leinen, M., Rea, D.K., Becker, K., Boulègue, J.J., Erzinger, J., Gieskes, J.M., Hobart, M.A., Kastner, M., Knüttel, S., Lyle, M.W., Moos, D., Newmark, R.L., Nishitani, T., Owen, R.M., Pearce, J.A., Romine, K., 1986. Site 
597. In: Leinen, M., Rea, D.K., et al. (Eds.), Init. Repts. DSDP. Washington (U.S. Govt. Printing Office), 92, $25-96$.

Maher, K.C., Larson, P.B., 2007. Variation in copper isotope ratios and controls on fractionation in hypogene skarn mineralization at Coroccohuayco and Tintaya, Peru. Econ. Geol. 102, 225-237.

Marchig, V., Erzinger, J., Heinze, P.M., 1986. Sediment in the black smoker area of the East Pacific Rise (18.5 ${ }^{\circ}$ ). Earth Planet. Sci. Lett. 79, 93-106.

Maréchal, C.N., Télouk, P., Albarède, F., 1999. Precise analysis of copper and zinc isotopic compositions by plasmasource mass spectrometry. Chem. Geol. 156, 251-273.

Markl, G., Lahaye, Y., Schwinn, G., 2006. Copper isotopes as monitors of redox processes in hydrothermal mineralization. Geochim. Cosmochim. Acta 70, 4215-4228.

Mason, T.F.D., Weiss, D.J., Chapman, J.B., Wilkinson, J.J., Tessalina, S.G., Spiro, B., Horswood, M.S.A., Spratt, J., Coles, B.J., 2005. $\mathrm{Zn}$ and $\mathrm{Cu}$ isotopic variability in the Alexandrinka volcanic-hosted massive sulphide (VHMS) ore deposit, Urals, Russia. Chem. Geol. 221, 170-187.

Mathur, R., Ruiz, J., Titley, S., Liermann, L., Buss, H., Brantley, S., 2005. Cu isotopic fractionation in the supergene environment with and without bacteria. Geochim. Cosmochim. Acta 69, 5233-5246.

Mathur, R., Titley, S., Barra, F., Brantley, S., Wilson, M., Phillips, A., Munizaga, F., Makseav, V., Vervoort, J., Hart, G., 2009. Exploration potential of $\mathrm{Cu}$ isotope fractionation in Porphyry Copper deposits. J. Geochem. Explor. 102, 1-6.

Miller, C., Thöni, M., Frank, W., Schuster, R., Melcher, F., Meisel, T., Zanetti, A., 2003. Geochemistry and tectonomagmatic affinity of the Yungbwa ophiolite, SW Tibet. Lithos 66, 155-172.

Minniti, M., Bonavia, F.F., 1984. Copper-ore grade hydrothermal mineralization discovered in a seamount in the Tyrrhenian Sea (Mediterranean): Is mineralization related to porphyry-copper or to base metal lodes? Mar. Geol. 59, 271-282.

Moeller, K., Schoenberg, R., Pedersen, R.-B., Weiss, D., Dong, S., 2012. Calibration of the new certified reference materials ERM-AE633 and ERM-AE647 for copper and IRMM-3702 for zinc isotope amount ratio determinations. Geostand. Geoanal. Res. 36, 177-199.

Mottl, M.J., McConachy, T.F., 1990. Chemical processes in buoyant hydrothermal plumes on the East Pacific Rise near $21^{\circ}$ N. Geochim. Cosmochim. Acta 54, 1911-1927. 
Moynier, F., Koeberl, C., Beck, P., Jourdan, F., Telouk, P., 2010. Isotopic fractionation of Cu in tektites. Geochim. Cosmochim. Acta 74, 799-807.

Nagle, F., Fink, L.K., Boström, K., Stipp, J.J., 1973. Copper in pillow basalts from La Desirade, Lesser Antilles island arc. Earth Planet. Sci. Lett. 19, 193-197.

Nishitani, T., 1986. Electron microprobe and thermomagnetic analysis of basalt samples from Hole 597C. In: Leinen, M., Rea, D.K., et al. (Eds.), Init. Repts. DSDP. Washington (U.S. Govt. Printing Office), 92, 481-489.

Ono, S., Keller, N.S., Rouxel, O., Alt, J.C., 2012. Sulfur-33 constraints on the origin of secondary pyrite in altered oceanic basement. Geochim. Cosmochim. Acta 87, 323-834.

Ovenshine, A.T., Winkler, G.R., Andrews, P.B., Gostin, V.A., 1975. Chemical analyses and minor element composition of Leg 29 basalts. In: Kennett, J.P., Houtz, R.E., et al. (Eds.), Init. Repts. DSDP. Washington (U.S. Govt. Printing Office), 29, 1097-1102.

Palacios, C., Rouxel, O., Reich, M., Cameron, E.M., Leybourne, M.I., 2011. Pleistocene recycling of copper at a porphyry system, Atacama Desert, Chile: Cu isotope evidence. Miner. Deposita 46, 1-7.

Pearce, C.I., Pattrick, R.A.D., Vaughan, D.J., Henderson, C.M.B., van der Laan, G., 2006. Copper oxidation state in chalcopyrite: Mixed $\mathrm{Cu} d^{9}$ and $d^{10}$ characteristics. Geochim. Cosmochim. Acta 70, 4635-4642.

Peterson, C., Duncan, R., Scheidegger, K.F., 1986. Sequence and longevity of basalt alteration at Deep Sea Drilling Project Site 597. In: Leinen, M., Rea, D.K., et al. (Eds.), Init. Repts. DSDP. Washington (U.S. Govt. Printing Office), 92, 505-515.

Pinto, V.M., Hartmann, L.A., Wildner, W., 2011. Epigenetic hydrothermal origin of native copper and supergene enrichment in the Vista Alegre district, Paraná basaltic province, southernmost Brazil. International Geology Review 53, 1163-1179.

Pokrovsky, O.S., Viers, J., Emnova, E.E., Kompantseva, E.I., Freydier, R., 2008. Copper isotope fractionation during its interaction with soil and aquatic microorganisms and metal oxy(hydr)oxides: Possible structural control. Geochim. Cosmochim. Acta 72, 1742-1757.

Puchelt, H., Prichard, H.M., Berner, Z., Maynard, J., 1996. Sulfide mineralogy, sulfur content and sulfur isotope composition of mafic and ultramafic rocks from Leg 147. In: Mével, C., Gillis, K.M., Allan, J.F., Meyer, P.S., (Eds.), Proc. ODP, Sci. Results. 147, 91-101.

Ramdohr, P., 1980. The Ore Minerals and Their Intergrowths. Pergamon Press, Oxford. 
Roberts, D.G., Schnitker, D., Backman, J., Baldauf, J.G., Desprairies, A., Homrighausen, R., Huddlestun, P., Kaltenback, A.J., Keene, J.B., Krumsiek, K.A.O., Morton, A.C., Murray, J.W., Westberg-Smith, J., Zimmerman, H.B., 1984. Sites 552-553. In: Roberts, D.G., Schnitker, D., et al. (Eds.), Init. Repts. DSDP. Washington (U.S. Govt. Printing Office), 81, 31-233.

Rouxel, O., Dobbek, N., Ludden, J., Fouquet, Y., 2003. Iron isotope fractionation during oceanic crust alteration. Chem. Geol. 202, 155-182.

Rouxel, O., Fouquet, Y., Ludden, J.N., 2004. Copper isotope systematics of the Lucky Strike, Rainbow, and Logatchev sea-floor hydrothermal fields on the Mid-Atlantic Ridge. Econ. Geol. 99, 585-600.

Rouxel, O., Ono, S., Alt, J., Rumble, D., Ludden, J., 2008. Sulfur isotope evidence for microbial sulfate reduction in altered oceanic basalts at ODP Site 801. Earth Planet. Sci. Lett. 268, 110-123.

Schlanger, S.O., Jackson, E.D., Boyoce, R.E., Cook, H.E., Jenkyns, H.C., Johnson, D.A., Kaneps, A.G., Kelts, K.R., Martini, E., McNulty, C.L., Winterer, E.L., 1976. Site 317. In: Schlanger, S.O., Jackson, E.D., et al. (Eds.), Init. Repts. DSDP. Washington (U.S. Govt. Printing Office), 33, 161-300.

Seo, J.H., Lee, S.K., Lee, I., 2007. Quantum chemical calculations of equilibrium copper (I) isotope fractionations in ore-forming fluids. Chem. Geol. 243, 225-237.

Seyfried, Jr. W.E., Bischoff, J.L., 1979. Low temperature basalt alteration by seawater: an experimental study at $70^{\circ} \mathrm{C}$ and $150^{\circ} \mathrm{C}$. Geochim. Cosmochim. Acta 43, 1937-1947.

Sharkov, E.V., Abramov, S.S., Simonov, V.A., Krinov, D.I., Skolotnev, S.G., Bel’tenev, V.E., Bortnikov, N.S., 2007. Hydrothermal alteration and sulfide mineralization in gabbroids of the Markov Deep (Mid-Atlantic Ridge, $\left.6^{\circ} \mathrm{N}\right)$. Geology of Ore Deposits 49, 467-486.

Shields, W.R., Goldich, S.S., Garner, E.L., Murphy, T.J., 1965. Natural variations in the abundance ratio and the atomic weight of copper. J. Geophys. Res. 70, 479-491.

Siesser, W.G., 1978. Native copper in DSDP Leg 40 sediments. In: Bolli, H.M., Ryan, W.B.F., et al. (Eds.), Init. Repts. DSDP. Washington (U.S. Govt. Printing Office), Supplement to volumes 38, 39, 40 and 41, 761-765.

Singer, P.C., Stumm, W., 1970. Acidic mine drainage: The rate-determining step. Science 167, 1121-1123.

Takano, S., Tanimizu, M., Hirata, T., Sohrin, Y., 2013. Determination of isotopic composition of dissolved copper in seawater by multi-collector inductively coupled plasma mass spectrometry after pre-concentration using an ethylenediaminetriacetic acid chelating resin. Anal. Chim. Acta 784, 33-41. 
Talwani, M., Udintsev, G.B., Bjørklund, K., Caston, V.N.D., Faas, R.W., van Hinte, J.E., Kharin, G.N., Morris, D.A., Müller, C., Nilsen, T.H., Warnke, D.A., White, S.M., 1976. Sites 338-343. In: Talwani, M., Udintsev, G.B., et al. (Eds.), Init. Repts. DSDP. Washington (U.S. Govt. Printing Office), 38, 151-387.

Teagle, D.A.H., Alt, J.C., 2004. Hydrothermal alteration of basalts beneath the Bent Hill massive sulfide deposit, Middle Valley, Juan de Fuca Ridge. Econ. Geol. 99, 561-584.

Thompson, C.M., Ellwood, M.J., Wille, M., 2013. A solvent extraction technique for the isotopic measurement of dissolved copper in seawater. Anal. Chim. Acta 775, 106-113.

Thompson, G., Bryan, W.B., Frey, F.A., Sung, C.M., 1974. Petrology and geochemistry of basalts and related rocks from Sites 214, 215, 216, DSDP Leg 22, Indian Ocean. In: von der Borch, C.C., Sclater, J.G., et al. (Eds.), Init. Repts. DSDP. Washington (U.S. Govt. Printing Office), 22, 213-265.

Tossell, J.A., 2005. Calculating the partitioning of the isotopes of Mo between oxidic and sulfidic species in aqueous solution. Geochim. Cosmochim. Acta 69, 2981-2993.

Vance, D., Archer, C., Bermin, J., Perkins, J., Statham, P., Lohan, M., Ellwood, M., Mills, R., 2008. The copper isotope geochemistry of rivers and the oceans. Earth Planet. Sci. Lett. 274, 204-213.

von der Borch, C.C., Sclater, J.G., Gartner, S., Hekinian, R., Johnson, D.A., McGowran, B., Pimm, A.C., Thompson, R.W., Veevers, J.J., Waterman, L.S., 1974. Site 216. In: von der Borch, C.C., Sclater, J.G., et al. (Eds.), Init. Repts. DSDP. Washington (U.S. Govt. Printing Office), 22, 213-265.

Walker, E.C., Cuttitta, F., Senftle, F.E., 1958. Some natural variations in the relative abundance of copper isotopes. Geochim. Cosmochim. Acta 15, 183-194.

Wang, C.Y., Zhou, M.-F., Qi, L., Hou, S.G., Gao, H.G., Zhang, Z.W., Malpas, J., 2006. The Zhaotong native copper deposit associated with the Permian Emeishan flood basalts, Yunnan, Southwest China. International Geology Review 48, 742-753.

Wheat, C.G., Mottl, M.J., 2000. Composition of pore and spring waters from Baby Bare: Global implications of geochemical fluxes from a ridge flank hydrothermal system. Geochim. Cosmochim. Acta 64, 629-642.

Wheat, C.G., Elderfield, H., Mottl, M.J., Monnin, C., 2000. Chemical composition of basement fluids within an oceanic ridge flank: Implications for along-strike and across-strike hydrothermal circulation. J. Geophys. Res. $105, \mathrm{~B} 6,13,437-13,447$. 
Wheat, C.G., Mottl, M.J., Rudnicky, M., 2002. Trace element and REE composition of a low-temperature ridgeflank hydrothermal spring. Geochim. Cosmochim. Acta 66, 3693-3705.

Wheat, C.G., Jannasch, H.W., Kastner, M., Plant, J.N., DeCarlo, E.H., 2003. Seawater transport and reaction in upper oceanic basaltic basement: chemical data from continuous monitoring of sealed boreholes in a ridge flank environment. Earth Planet. Sci. Lett. 216, 549-564.

Wheat, C.G., Jannasch, H.W., Fisher, A.T., Becker, K., Sharkey, J., Hulme, S., 2010. Subseafloor seawater-basaltmicrobe reactions: Continuous sampling of borehole fluids in a ridge flank environment. Geochem. Geophys. Geosyst. 11, Q07011, doi:10.1029/2010GC003057.

Zemmels, I., Cook, H.E., Hathaway, J.C., 1972. X-ray mineralogy studies - Leg 11. In: Hollister, C.D., Ewing, J.I., et al. (Eds.), Init. Repts. DSDP. Washington (U.S. Govt. Printing Office), 11, 729-789.

Zhu, X.K., O’Nions, R.K., Guo, Y., Belshaw, N.S., Rickard, D., 2000. Determination of natural Cu-isotope variation by plasma-source mass-spectrometry: implications for use as geochemical tracers. Chem. Geol. 163, $139-149$.

Zhu, X.K., Guo, Y., Williams, R.J.P., O’Nions, R.K., Matthews, A., Belshaw, N.S., Canters, G.W., de Waal, E.C., Weser, U., Burgess, B.K., Salvato, B., 2002. Mass fractionation processes of transition metal isotopes. Earth Planet. Sci. Lett. 200, 47-62. 


\section{Figure captions}

Fig. 1. Map with locations and lithologic columns for DSDP/ODP sites with native $\mathrm{Cu}$ occurrences discussed in this paper. $1=$ spreading centers; $2=$ subduction zones; $3=$ number and position of DSDP/ODP sites with native $\mathrm{Cu}$ occurrences analyzed in this study; 4 = number and position of DSDP/ODP sites with reported native Cu occurrences not found and analyzed in this study; $5=$ number and position of DSDP/ODP sites with reported native $\mathrm{Cu}$ occurrences not provided for this study; $6=$ silty clay; $7=$ hemipelagic clay; $8=$ nannofossil ooze; $9=$ dolomite; 10 $=$ radiolarian ooze; $11=$ pelagic clay; $12=$ scattered glauconite grains; $13=$ volcanic ash; $14=$ sapropels; $15=$ nanno chalk; 16 = limestone; 17 = igneous rocks (basalts \pm andesites); $18=$ dikes; $19=$ native $\mathrm{Cu}$ occurrences investigated in this work.

Fig. 2. (A) Photograph (stereo-microscope) of a leaf of native $\mathrm{Cu}$ (dark red) with specks of light blue mineral phase from an open crack in basalt [sample 22-216-37-4 (114-117)]; (B) micrograph (reflected light, optical microscope) of native $\mathrm{Cu}$ particle in basalt rock [sample 92-597C-4-2 5E (134-135), polished section]; (C) micrograph (reflected light, optical microscope) of native $\mathrm{Cu}$ vein in basalt rock [sample 92-597C-7-3 16 (135-138), polished section]; (D) SEM micrograph (SEI) of native Cu crystals [sample 11-105-38-2 (110-112)]; (E) SEM micrograph (SEI) of the surface of a native Cu leaf [sample 22-216-37-4 (114-117)]; (F) SEM micrograph (SEI) of light blue mineral phase $(\mathrm{Cu}, \mathrm{O}, \mathrm{Cl}$ composition; EDS studies) on the surface of a native $\mathrm{Cu}$ particle [sample 22-216-37-4 (114-117)]; (G) SEM micrograph (SEI) of light blue mineral phase ( $\mathrm{Cu}, \mathrm{S}, \mathrm{Cl}, \mathrm{O}$ composition; EDS studies) on the surface of a native $\mathrm{Cu}$ particle [sample 92-597C-7-3 16 (135-138)]; (H) SEM micrograph (SEI) of light blue mineral phase (Cu, $\mathrm{Cl}$, O composition; EDS studies) on the surface of a native $\mathrm{Cu}$ particle [sample 22-216-37-4 (114-117)].

Fig. 3. Reflectance spectra of native $\mathrm{Cu}$ [22-216-37-4 (114-117)] obtained in air (closed circles) and in oil (closed squares) compared with spectra of native Cu (QDF3) from the Botallack mine, Cornwall, UK (Criddle and Stanley, 1993) measured in air (open circles) and oil (open squares). 
Fig. 4. RBS depth profiles of the main elements detected through PIXE point analyses at natural surface of native $\mathrm{Cu}$ grains: (A) sample 22-216-37-4 (114-117); (B) sample 92-597C-4-2D (60-65). Analyses \#1 and \#2 as in Table 2.

Fig. 5. Eh- $\mathrm{pH}$ phase diagrams for the $\mathrm{Cu}$ system calculated at $\mathrm{P}=1 \mathrm{~atm}, \mathrm{~T}=60^{\circ} \mathrm{C}, \mathrm{a}[\mathrm{Cu}]=5.6 \mathrm{E}-9$, and $\mathrm{a}[\mathrm{Cl}]=0.55$. (a) stability fields of $\mathrm{Cu}$ fluid speciation and minerals with $\mathrm{a}\left[\mathrm{SO}_{4}\right]=0.018$ added to the system; (b) stability fields of $\mathrm{Cu}$ fluid speciation and minerals with $\mathrm{a}\left[\mathrm{SO}_{4}\right]=0.018$ and a[Fe] $=1 \mathrm{E}-9$ added to the system; (c) stability fields of the $\mathrm{S}$ fluid speciation under the same system conditions as plot (a); (d) stability fields of $\mathrm{Cu}$ fluid speciation and minerals with no $\mathrm{SO}_{4}$ and $\mathrm{Fe}$, where native $\mathrm{Cu}$ is most likely to form; (e) stability fields of $\mathrm{Cu}$ fluid speciation and minerals in a system with no $\mathrm{SO}_{4}$, but with a[Fe] $=1 \mathrm{E}-9$ added to the system.

Fig. 6. Different $\mathrm{Cu}$-isotope pools at the seafloor and model diagram of $\mathrm{Cu}^{0}$ precipitation in the oceanic basement as a result of low-temperature hydrothermal activity. Conception for low-temperature ("cool" and "warm") hydrothermal systems is after Wheat et al. (2002). Cold and oxic seawater enters basement at the MOR crest, alters (warms and becomes anoxic) during its flow within the crust and vents out the discharge zones. Favorable conditions for $\mathrm{Cu}^{0}$ precipitation (Fig. $5 \mathrm{~d}$ ) are attained in the anoxic and $\mathrm{H}_{2} \mathrm{~S}$-deficient domains achieved due to the very limited $\mathrm{SO}_{4}{ }^{2-}$ reduction extent in the volcanic basement (Ono et al., 2011), or diffusing exchange of $\mathrm{SO}_{4}{ }^{2-}$ (i.e., net loss) with the overlying organic-rich sediment (Elderfield et al., 1999). In addition to the low background $\mathrm{Cu}$ flux with lithogenic matter the sediment blanket obtains hydrogenous (adsorbed from seawater on hydrogenous Mn-Feoxyhydroxides) and hydrothermal (hydrothermal plume fallout) $\mathrm{Cu}$ that might eventually be diagenetically remobilized and reprecipitated as $\mathrm{Cu}^{0}$. 


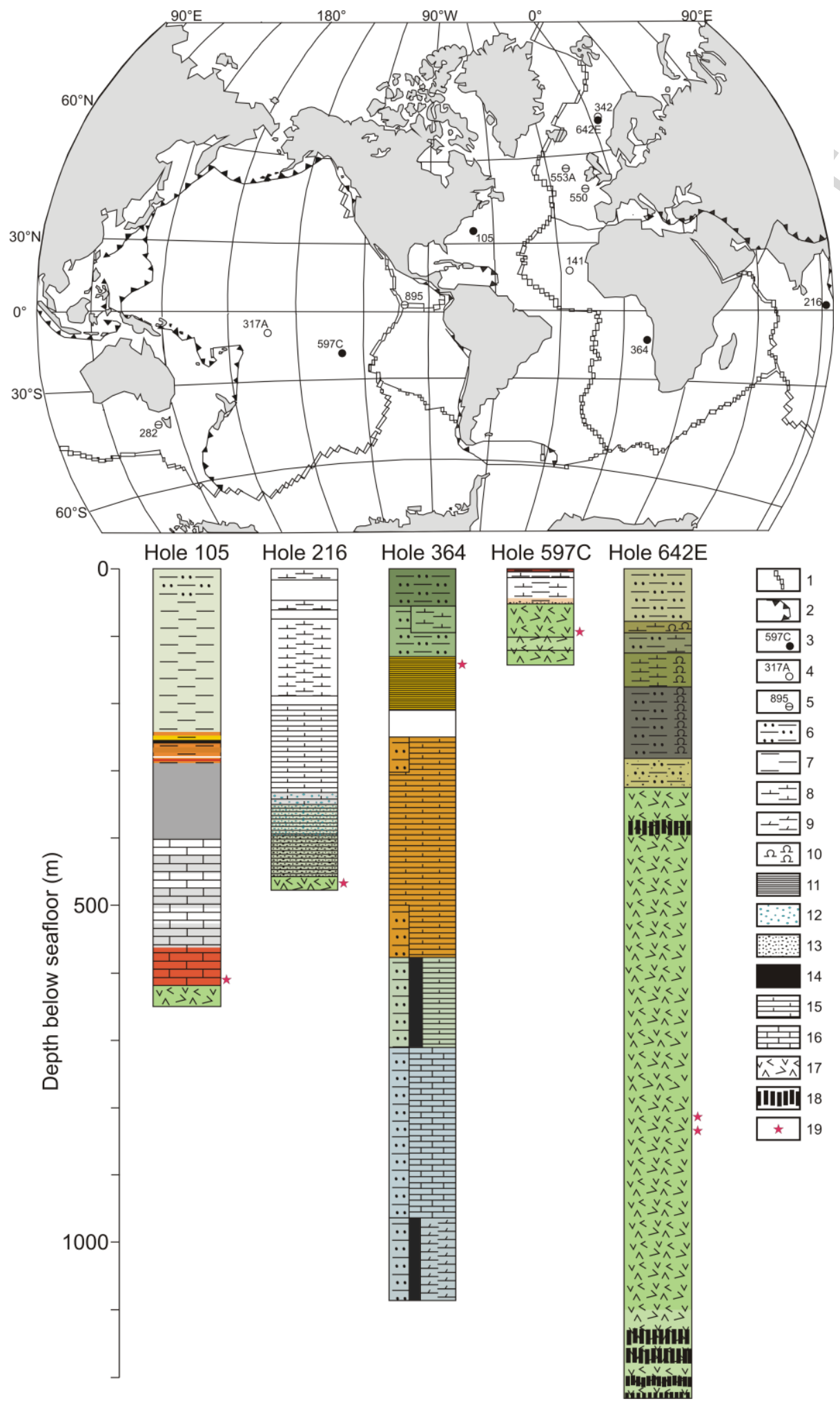

Fig. 1 

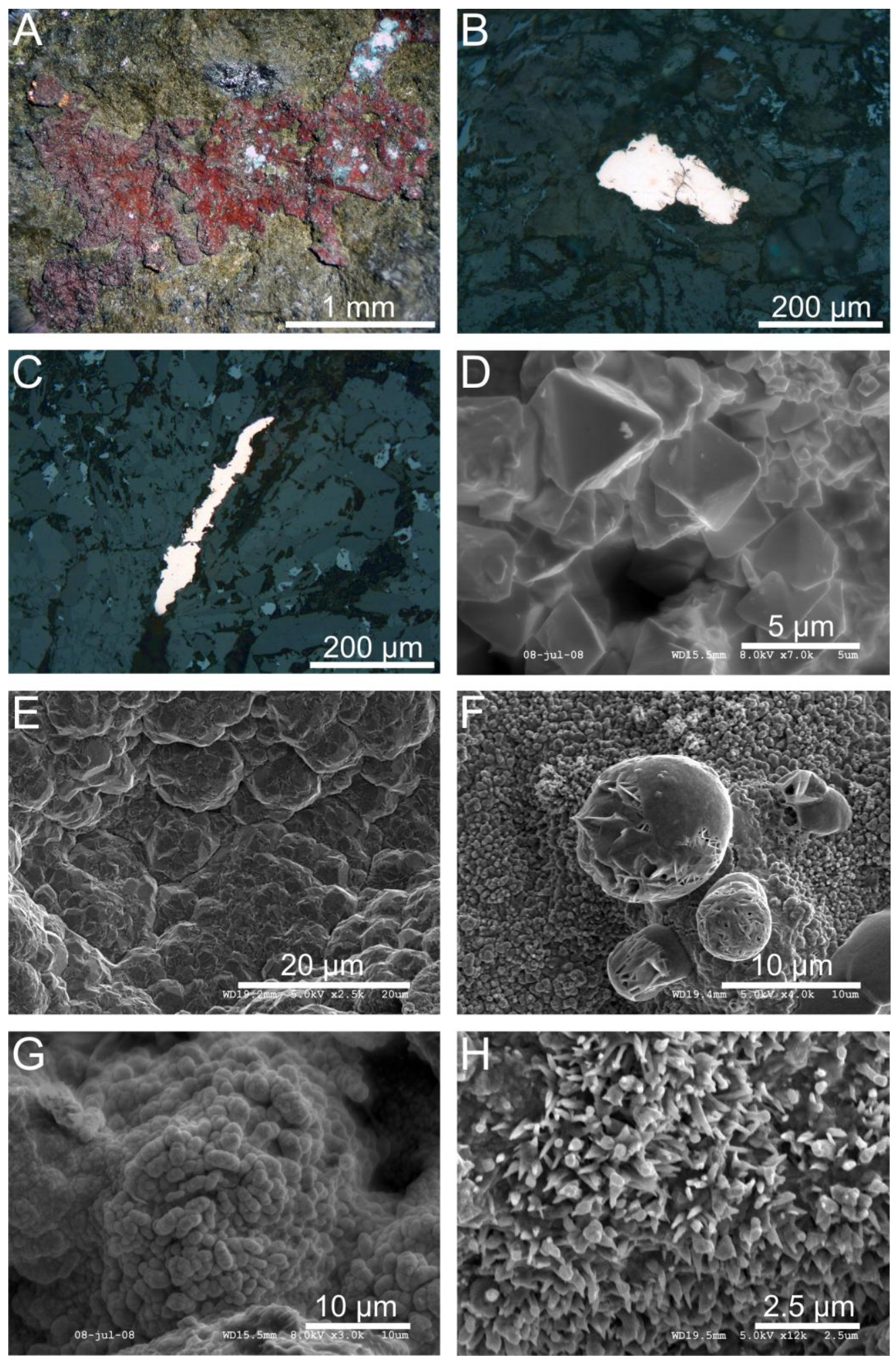

Fig. 2 


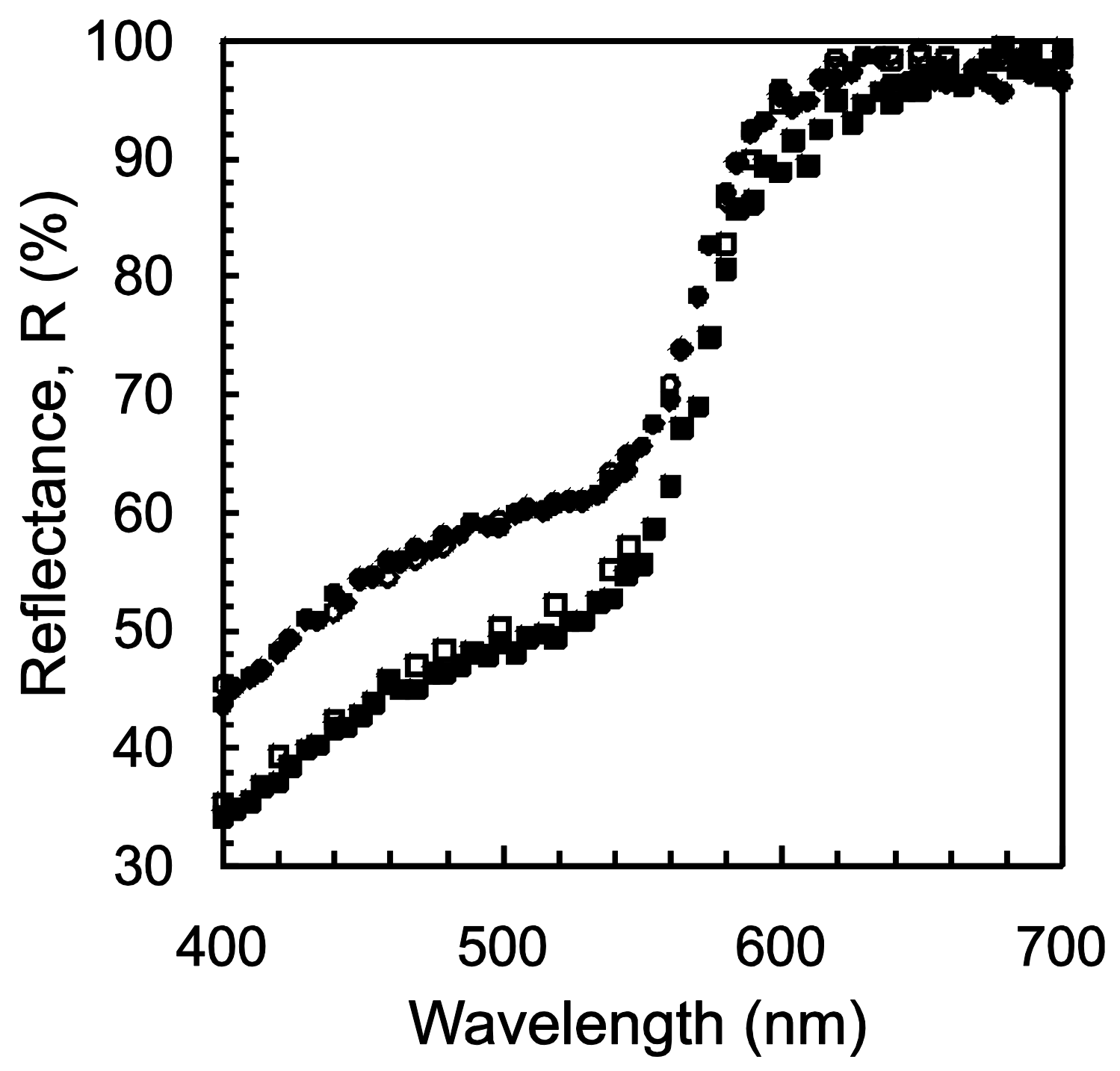

Fig. 3 

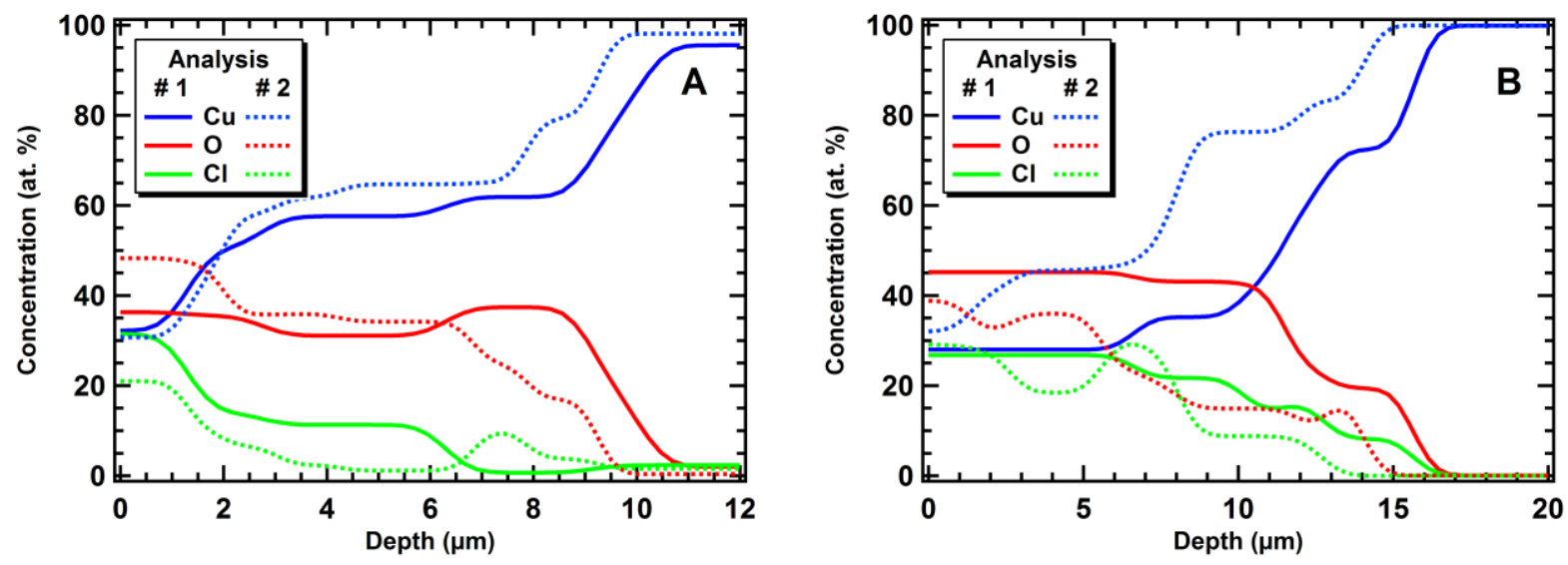

Fig. 4 

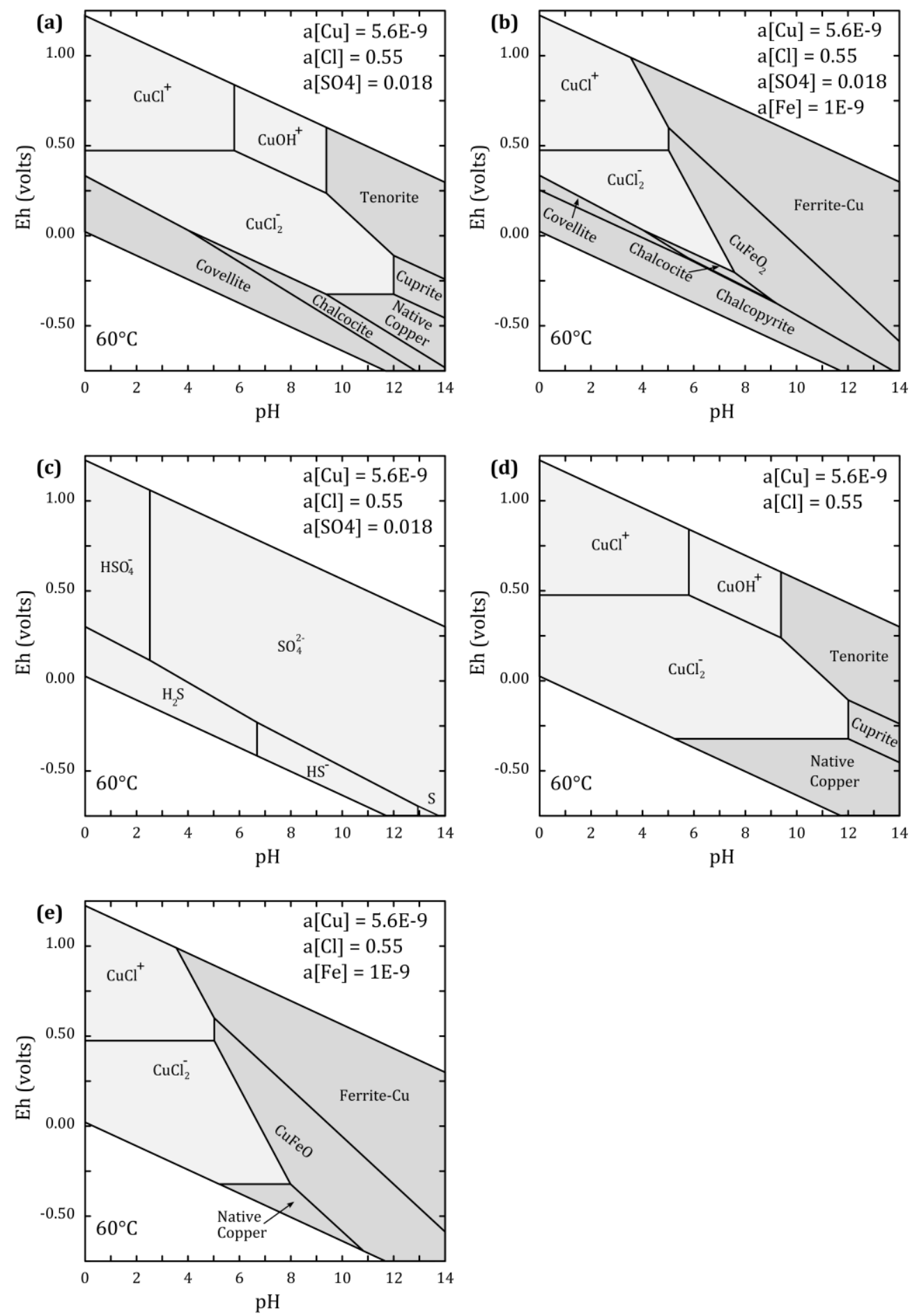

Fig. 5 


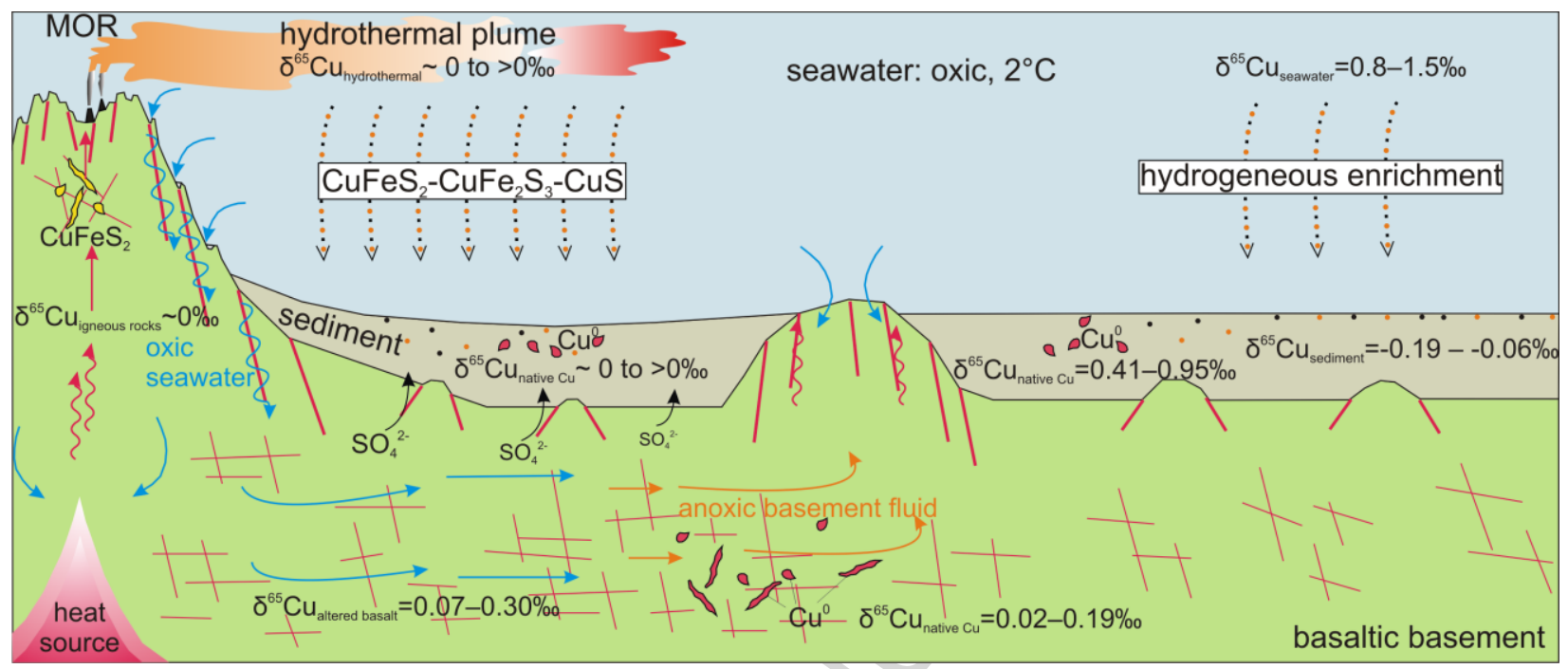

Fig. 6 
Table 1

Sample locations for investigated native $\mathrm{Cu}$ occurrences.

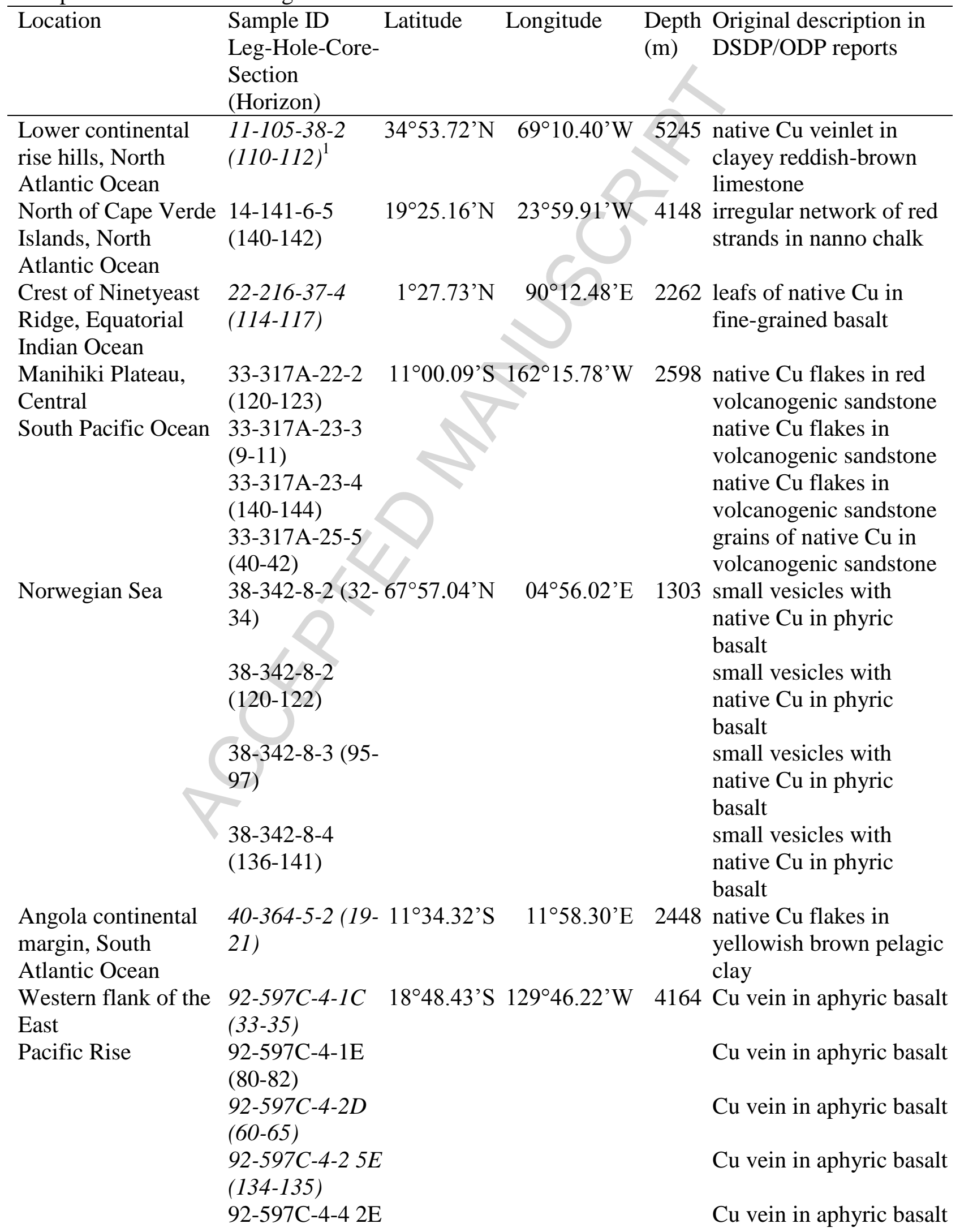


(104-107)

92-597C-4-4 $2 F$

(120-124)

92-597C-7-3 15

(121-125)

92-597C-7-3 16

(135-138)

Vøring Plateau,

Norwegian

Sea

104-642E-64R-

$2(78-80)$

104-642E-66R-

$2(19-22)$

104-642E-69R-

$2(112-115)$

104-642E-85R5 (86-88)
$\mathrm{Cu}$ vein in aphyric basalt

$\mathrm{Cu}$ vein in fine-grained aphyric basalt

$\mathrm{Cu}$ vein in fine-grained aphyric basalt

$2^{\circ} 55.7^{\prime} \mathrm{E} 1286 \mathrm{Cu}$ vein in fine-grained, aphyric, gray basalt $\mathrm{Cu}$ vein in fine-grained, phyric, gray basalt Cu blebs in dark, red brown tuff

$\mathrm{Cu}$ blebs in dark, red brown, well sorted, vitric, lithic tuff

${ }^{\mathrm{I}}$ In italic, samples where native $\mathrm{Cu}$ has been found and analyzed in the course of this study. 


\section{Table 2}

Composition (PIXE analyses on natural surface) $)^{1}$ of native $\mathrm{Cu}$ occurrences.

\begin{tabular}{|c|c|c|c|c|c|c|c|c|c|c|}
\hline $\begin{array}{l}\text { Sample ID } \\
\text { Leg-Hole-Core- } \\
\text { Section (Horizon) }\end{array}$ & $\begin{array}{l}\text { Analysis } \\
\#\end{array}$ & $\begin{array}{l}\mathrm{Cu} \\
\mathrm{wt} . \\
\%\end{array}$ & $\mathrm{O}^{2}$ & $\mathrm{Cl}$ & $\mathrm{Fe}$ & $\mathrm{Si}$ & $\mathrm{Ca}$ & $\begin{array}{l}\text { As } \\
\text { ppm }\end{array}$ & $\mathrm{K}$ & $\mathrm{Mn}$ \\
\hline \multirow[t]{2}{*}{$\begin{array}{l}22-216-37-4 \text { (114- } \\
117)\end{array}$} & 1 & 80.7 & 10.3 & 8.93 & 0.10 & & b.d.l. & b.d.l. & b.d.l. & b.d.l. \\
\hline & 2 & 87.7 & 11.2 & 0.79 & 0.29 & & b.d.l. & b.d.l. & b.d.l. & b.d.l. \\
\hline \multirow[t]{2}{*}{$\begin{array}{l}92-597 C-4-2 D(60- \\
65)\end{array}$} & 1 & 73.4 & 9.59 & 16.3 & & b.d.1. & 0.18 & 856 & b.d.l. & b.d \\
\hline & 2 & 74.5 & 11.7 & 10.0 & 2.28 & 1.25 & 0.17 & 522 & 395 & 222 \\
\hline
\end{tabular}

${ }^{1}$ Average concentrations for point measurements under the assumption that the $\mathrm{Cu}^{0}$ particles are homogeneous in depth and the main additional elements in the surface films are $\mathrm{O}$ and $\mathrm{Cl}$ (see the RBS data). It should be noted that the samples are inhomogeneous and therefore these results contain systematic deviations.

${ }^{2}$ Calculated from concentrations of the other elements assuming they are present in their oxidized form and using their stoichiometric relations with $\mathrm{O}$. The assumption of oxidized states is justified by the simultaneous RBS measurements that show presence of $\mathrm{O}$ in the outer $\sim 10 \mu \mathrm{m}$ film of the samples.

${ }^{3}$ b.d.l. $=$ below detection limit. 
Table 3

$\mathrm{Cu}$-isotope composition of native $\mathrm{Cu}$ occurrences, their host rocks and some reference materials.

\begin{tabular}{|c|c|c|c|c|c|}
\hline $\begin{array}{l}\text { Sample ID } \\
\text { Leg-Hole-Core-Section (Horizon) }\end{array}$ & Type & $\begin{array}{l}\mathrm{Cu} \\
\mathrm{ppm}\end{array}$ & $\mathrm{N}^{1}$ & $\begin{array}{l}\delta^{65} \mathrm{Cu} \\
\% 0\end{array}$ & $1 \mathrm{SD}$ \\
\hline \multirow[t]{5}{*}{$11-105-38-2(110-112)$} & native $\mathrm{Cu}$ & & 6 & 0.41 & 0.03 \\
\hline & native $\mathrm{Cu}$ & & 4 & 0.49 & 0.07 \\
\hline & bluish phase around $\mathrm{Cu}^{0}$ & & & 0.21 & 0.03 \\
\hline & bluish phase around $\mathrm{Cu}^{0}$ & & 4 & -0.09 & 0.04 \\
\hline & clayey reddish-brown limestone & & 4 & -0.06 & 0.01 \\
\hline \multirow[t]{5}{*}{ 22-216-37-4 (114-117) } & native $\mathrm{Cu}$ & & 6 & 0.18 & 0.02 \\
\hline & native $\mathrm{Cu}$ & & 4 & 0.14 & 0.03 \\
\hline & native $\mathrm{Cu}$ & & 4 & 0.16 & 0.03 \\
\hline & native $\mathrm{Cu}$ & & 4 & 0.19 & 0.02 \\
\hline & basalt & 0 & 4 & 0.30 & 0.02 \\
\hline \multirow{2}{*}{$40-364-5-2(19-21)$} & native $\mathrm{Cu}$ with bluish phase arou & & 4 & 0.95 & 0.06 \\
\hline & yellowish browi & 35 & 4 & -0.19 & 0.02 \\
\hline \multirow{2}{*}{$92-597 C-7-316(135-138)$} & native $\mathrm{Cu}$ & & 6 & 0.02 & 0.01 \\
\hline & basalt & 325 & 4 & 0.07 & 0.03 \\
\hline 1149A-20X1, $140^{2}$ & deep-sea clays & 192 & 4 & 0.01 & 0.02 \\
\hline $1149 \mathrm{C}-02 \mathrm{~W} 1,31^{2}$ & Mn-rich cherts & 504 & 4 & 0.37 & 0.03 \\
\hline 1149C-11R1, 19/D 2 & altered basalt & 63 & 4 & 0.00 & 0.03 \\
\hline $801 \mathrm{C}-44 \mathrm{R} 3,32 / \mathrm{V}+\mathrm{H}^{2}$ & altered basalt & 148 & 4 & 0.11 & 0.04 \\
\hline
\end{tabular}

${ }^{1}$ Number of duplicates analysed.

${ }^{2}$ Samples described in Rouxel et al. (2003). 
Table 4

$\mathrm{Cu}$-isotope composition of native $\mathrm{Cu}$ occurrences from different deposits.

\begin{tabular}{|c|c|c|c|c|c|c|}
\hline Sample ID & Mineral & Locality & Deposit type & $\begin{array}{l}\delta^{65} \mathrm{Cu} \\
\% 0\end{array}$ & $1 \mathrm{SD}$ & Reference \\
\hline 84 & native $\mathrm{Cu}$ & Pima, Arizona, USA & pyrometasomatic & 2.0 & & $\begin{array}{l}\text { Shields et al., } \\
1965\end{array}$ \\
\hline 85 & - “ - & Soudan mine, Minnesota, USA & & 0.9 & & $-“$ \\
\hline 86 & - “ & Azaruzawa, Rikuchiu, Japan & & -0.3 & & - “ \\
\hline 87 & - “ - & Copper River, Alaska, USA & hydrothermal & -0.3 & & $-“$ \\
\hline 88 & - “ & Lake Superior district, Michigan, USA & - “ & -1.0 & & - “ \\
\hline 89 & - “ & Corocoro, Bolivia & & -1.1 & & - “ \\
\hline 90 & - “ & Painesdale, Michigan, USA & $-“$ & -1.3 & & - “ - \\
\hline LS-7 & - “ & Trimountain Mine, Michigan, USA & & 0.27 & & Larson et al., 2003 \\
\hline LS-10 & $-“-$ & Baltic Mine, Michigan, USA & & $\begin{array}{l}0.29 \\
(\text { mean })\end{array}$ & 0.04 & $-“-$ \\
\hline LS-12 & - “ & Centennial Mine, Michigan, USA & & 0.26 & & - “ \\
\hline LS-45 & - “ - & Isle Royale Mine, Michigan, USA & & 0.34 & & - “ - \\
\hline LS-48 & - “ & Wolverine Mine, Michigan, USA & & 0.30 & & - “ \\
\hline LS-51 & $-“-$ & Copper Falls Mine, Michigan, US & & $\begin{array}{l}0.02 \\
\text { (mean) }\end{array}$ & 0.01 & $-“-$ \\
\hline Ray-1 & - “ - & Ray Mine, Arizona, USA & sup & $\begin{array}{l}-0.04 \\
(\text { mean })\end{array}$ & 0.04 & - “ - \\
\hline Ray-2 & $\begin{array}{l}\text { native } \mathrm{Cu}+ \\
\text { cuprite }\end{array}$ & - “ & $-“$ & 1.26 & & $-“-$ \\
\hline Ray-2b & native $\mathrm{Cu}$ & - “ & - “ & 0.72 & & - “ \\
\hline $\mathrm{CCP}-2$ & $-“-$ & Ccatun Pucara, Tintaya, Peru & - “ & -0.83 & & - “- \\
\hline & - “ - & Ray Mine, Arizona, USA & - “ & -3.03 & 0.04 & $\begin{array}{l}\text { Maréchal et al., } \\
1999\end{array}$ \\
\hline OUM22647 & - “ - & Bisbee, Arizona, USA & & -0.2 & & Zhu et al., 2000 \\
\hline OUM15126 & - “ & Michigan, USA & hydrothermal & 0.45 & & - “ \\
\hline OUM15120 & $-“-$ & Lake Superior, North America & $-“-$ & 0.54 & & $-“-$ \\
\hline OUM00061 & - “ & Yekaterinburg, Russia & & -0.33 & & - “ \\
\hline OUM15127 & - “ & Cornwall, England & & 0.41 & & - “ \\
\hline OUM00078 & - “ - & St. Cleer, Cornwall, England & & 1.25 & & - “ - \\
\hline NNB82 & - “ & Neubulach near Calw, Germany & supergene & -0.46 & 0.02 & Markl et al., 2006 \\
\hline $\mathrm{Cu} 3$ & - “ - & Prosper near Rippoldsau, Germany & - “- & 0.39 & - “- & $-“-$ \\
\hline Arizona $\mathrm{Cu}$ & - “ - & Morenci, Arizona, USA & & -0.51 & 0.07 & $\begin{array}{l}\text { Ikehata et al., } \\
2008\end{array}$ \\
\hline Mio 7-4 & - “- & $\begin{array}{l}\text { Mio mine, Sanbagawa metamorphic } \\
\text { belt, Japan }\end{array}$ & supergene & 1.57 & 0.02 & $\begin{array}{l}\text { Ikehata et al., } \\
2011\end{array}$ \\
\hline Mio 7-5 & - “ - & - “- & $-“-$ & 1.71 & 0.03 & 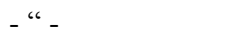 \\
\hline Mio 7-6 & - " - & 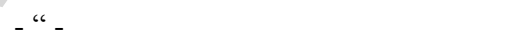 & - " & 1.65 & 0.02 & - “ \\
\hline Mio 7-7 & $-“-$ & $-"$ - & $-“-$ & 1.62 & 0.03 & $-“-$ \\
\hline Mio 8-4 & $-"$ & $-"$ - & - “- & 1.45 & 0.03 & $-\cdots$ \\
\hline Mio 8-5 & - “ & $-" \cdots$ & $-" \cdots$ & 1.54 & 0.02 & - “ \\
\hline Mio 8-6 & - “- & $-" \cdots$ & - “ & 1.43 & 0.02 & $-\cdots$ \\
\hline Mio 8-7 & - " - & - " - & - “- & 1.56 & 0.03 & - “ \\
\hline
\end{tabular}

